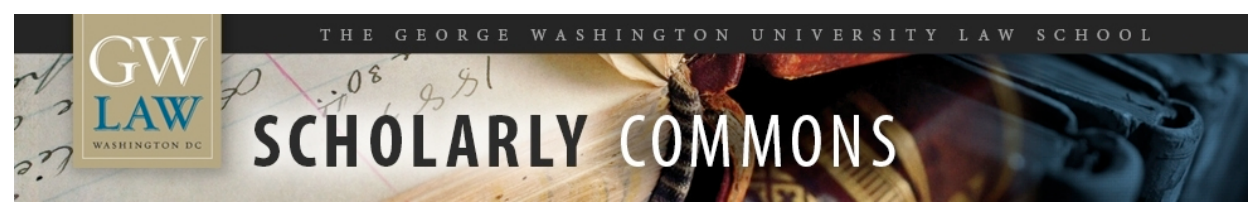

\title{
The Financial Industry's Plan for Resolving Failed Megabanks Will Ensure Future Bailouts for Wall Street
}

Arthur E. Wilmarth Jr.

George Washington University Law School, awilmarth@law.gwu.edu

Follow this and additional works at: https://scholarship.law.gwu.edu/faculty_publications

Part of the Law Commons

\section{Recommended Citation}

Wilmarth, Arthur E., The Financial Industry's Plan for Resolving Failed Megabanks Will Ensure Future Bailouts for Wall Street (2015). 50 Georgia Law Review (2015).; GWU Law School Public Law Research Paper No. 2015-36; GWU Legal Studies Research Paper No. 2015-36. Available at SSRN: http://ssrn.com/ abstract $=2648572$

This Article is brought to you for free and open access by the Faculty Scholarship at Scholarly Commons. It has been accepted for inclusion in GW Law Faculty Publications \& Other Works by an authorized administrator of Scholarly Commons. For more information, please contact spagel@law.gwu.edu. 


\title{
THE FINANCIAL INDUSTRY'S PLAN FOR RESOLVING FAILED MEGABANKS WILL ENSURE FUTURE BAILOUTS FOR WALL STREET
}

\author{
Arthur E. Wilmarth, Jr. *
}

TABLE OF CONTENTS

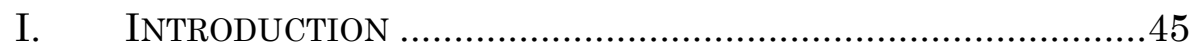

II. SPOE WOULD PRESERVE TBTF TREATMENT FOR SIFIS

AND WALL STREET CREDITORS WHILE IMPOSING

LOSSES ON ORDINARY INVESTORS AND TAXPAYERS

A. IN ITS EARLY RULEMAKINGS UNDER TITLE II, FDIC

RECOGNIZED DODD-FRANK'S LIQUIDATION-ONLY

MANDATE.

B. THE FINANCIAL INDUSTRY DEVELOPED SPOE TO

EVADE DODD-FRANK'S LIQUIDATION-ONLY MANDATE

AND TO GUARANTEE PROTECTION FOR WALL STREET

CREDITORS

C. WALL STREET'S SPOE STRATEGY WOULD ENSURE

FUTURE BAILOUTS FOR WALL STREET CREDITORS

AND IMPOSE LOSSES ON ORDINARY INVESTORS AND

TAXPAYERS

\footnotetext{
* Professor of Law, George Washington University Law School. I wish to thank Dean Blake Morant and GW Law School for a summer research grant that supported my work on this Article. I am indebted to my students, Kelsey Barnes and Velika Nespor, and to Germaine Leahy, Head of Reference at the Jacob Burns Law Library, for superb research assistance. I am grateful to Adam Levitin, Stephen Lubben, David Skeel, and Jay Westbrook for their helpful comments on a preliminary draft of this Article. Unless otherwise indicated, this Article includes developments through September 30, 2015.
} 
1. SPOE Would Protect Wall Street Creditors of Failed SIFIs.

2. Wall Street's Funding Plan for SPOE Resolutions

Would Impose Losses on Ordinary Investors and

Taxpayers

D. SPOE'S CLAIMED BENEFITS ARE HIGHLY DOUBTFUL AND DO NOT JUSTIFY BLANKET PROTECTION FOR

WALL STREET CREDITORS OF FAILED SIFIS

III. POLICYMAKERS SHOULD ADOPT TWO REFORMS TO REDUCE THE TBTF SUBSIDY EMBODIED IN WALL STREET'S SPOE PLAN

A. SIFIS SHOULD PAY RISK-ADJUSTED PREMIUMS TO PREFUND OLF .73

1. Prefunding OLF Would Reduce the TBTF Subsidy for SIFIs. .73

2. OLF Premiums Should Include Fees on ShortTerm Liabilities Held by SIFIs .76

B. SIFIS SHOULD PAY AT LEAST HALF OF THEIR COMPENSATION TO SENIOR EXECUTIVES AND OTHER KEY INSIDERS IN THE FORM OF COCOS.

1. Universal Banks Provide Extraordinary

Benefits to Insiders at the Expense of Taxpayers and Society. .79

2. SIFIs Should Pay Much of Their Compensation to Insiders in the Form of CoCos....

IV.

CONCLUSION . .86 


\section{INTRODUCTION}

Wall Street has achieved a remarkable political comeback from the financial crisis of 2007-2009. Public anger over bailouts of large financial institutions spurred Congress to pass the DoddFrank Wall Street Reform and Consumer Protection Act (DoddFrank) in July 2010. ${ }^{1}$ Megabanks, however, used their political influence to weaken Dodd-Frank's provisions, ${ }^{2}$ and they have pursued a determined campaign since 2010 to undermine DoddFrank's implementation. ${ }^{3}$

A primary goal of Dodd-Frank is to end "too big to fail" (TBTF) treatment for systemically important financial institutions (SIFIs) and their creditors. ${ }^{4}$ During the debates over Dodd-Frank, however, Wall Street defeated two major initiatives that would have threatened megabanks' TBTF status. First, Wall Street's political allies voted down a proposed amendment by Senators Sherrod Brown and Ted Kaufman, which would have forced a

1 Dodd-Frank Wall Street Reform and Consumer Protection Act, Pub. L. No. 111-203, 124 Stat. 1376 (2010) [hereinafter Dodd-Frank]. For discussions of high-risk activities by large financial firms that precipitated the financial crisis, as well as the federal government's bailouts of financial giants and the public anger that followed, see generally ALAN S. BLINDER, After the Music Stopped: The Financial Crisis, The Response, and the Work Ahead (2013); Arthur E. Wilmarth, Jr., The Dodd-Frank Act: A Flawed and Inadequate Response to the Too-Big-to-Fail Problem, 89 OR. L. REV. 951, 957-84, 1026-28 (2011) [hereinafter Wilmarth, Dodd-Frank]; Arthur E. Wilmarth, Jr., Turning a Blind Eye: Why Washington Keeps Giving in to Wall Street, 81 U. CIN. L. REV. 1283, 1290-93, 1345-66 (2013) [hereinafter Wilmarth, Blind Eye]; Arthur E. Wilmarth, Jr., A Two-Tiered System of Regulation Is Needed to Preserve the Viability of Community Banks and Reduce the Risks of Megabanks, 2015 MicH. ST. L. REV. 249, 256-76 [hereinafter Wilmarth, Two-Tiered System].

2 See, e.g., Wilmarth, Dodd-Frank, supra note 1, at 1029-34 (describing the financial industry's success in weakening the Volcker Rule and the Lincoln Amendment prior to Dodd-Frank's passage).

3 See Wilmarth, Blind Eye, supra note 1, at 1296-1312 (describing the financial industry's lobbying and litigation that undermined Dodd-Frank's implementation between July 2010 and mid-2013); Wilmarth, Two-Tiered System, supra note 1, at 323-32 (discussing the financial industry's continued campaign to obstruct Dodd-Frank's implementation between mid-2013 and the end of 2014); Adam Davidson, Wall Street Is Using the Power of Dodd-Frank Against Itself, N.Y. TIMES MAG., May 27, 2015, http:// www.nytimes.com/2015/05/31/magazine/wall-str eet-is-using-the-power-of-dodd-frank-itself.html (describing lobbying and litigation and a "myriad [of] other ways" in which Wall Street has worked "to change the letter of [DoddFrank] so as to alter its spirit").

${ }^{4}$ Dodd-Frank, 124 Stat. at 1376 (preamble). 
breakup of the six largest U.S. banks. ${ }^{5}$ Second, Wall Street's allies blocked proposals that would have required the largest financial institutions to pay risk-based premiums to prefund the Orderly Liquidation Fund (OLF). ${ }^{6}$ As discussed below, the OLF provides funding for resolving failed SIFIs under Title II of Dodd-Frank. ${ }^{7}$ Due to Wall Street's success in defeating the prefunding proposals, the OLF currently has a zero balance and must rely on borrowings from the Treasury Department (Treasury) and, ultimately, taxpayers. ${ }^{8}$

Large financial conglomerates (frequently called "universal banks") are determined to defend their current business model, which relies on government protection of depositors and "shadow banking" creditors to ensure low-cost funding for their speculative capital markets activities. ${ }^{9}$ In December 2014, Wall Street's congressional allies succeeded in repealing the Lincoln Amendment, which was enacted as Section 716 of Dodd-Frank. ${ }^{10}$ The Lincoln Amendment would have forced megabanks to incur significant additional costs by transferring many of their derivatives from their federally-insured bank subsidiaries to nonbank affiliates. ${ }^{11}$ Wall Street's determined campaign to repeal the Lincoln Amendment "provides compelling evidence that Wall Street's business model depends on the ability of large financial

${ }^{5}$ See, e.g., Wilmarth, Dodd-Frank, supra note 1, at 1055 n.454 (discussing the defeat of the Brown-Kaufman amendment, which would have imposed maximum size limits on large financial institutions); Wilmarth, Blind Eye, supra note 1, at 1366.

${ }_{6}$ See Arthur Wilmarth, Use Tiered Regulation to Preserve Small Banks, Keep Big Ones in Line, AM. BANKER, Apr. 2, 2015, http://www.americanbanker.com/bankthink/use-tiered-regula tion-to-protect-small-banks-keep-big-ones-in-line-1073578-1.html (discussing how Wall Street and its allies successfully defeated proposals to prefund the OLF).

7 See infra notes 92-101 and accompanying text (discussing the OLF).

8 Wilmarth, Dodd-Frank, supra note 1, at 999, 1015-18.

9 See infra Parts III.A.2, III.B.1 (describing how universal banks use governmentsubsidized funding to support their capital markets activities); see also infra note 165 and accompanying text (discussing the determination of top executives of global megabanks to maintain the universal banking model); Zoltan Pozsar et al., FED. RESERVE BANK OF N.Y., StAFF Report No. 458, Shadow BANKING 22-33, 46-64 (2010), available at http://ssrn. com/abstract=1645337 (describing how the "shadow banking" system provides "shadow bank deposits" to finance the activities of U.S. and foreign megabanks and how federal agencies protected shadow banking creditors during the financial crisis).

10 See Wilmarth, supra note 6.

11 Wilmarth, Two-Tiered System, supra note 1, at 329-32. 
conglomerates to keep exploiting the cheap funding provided by their 'too big to fail' subsidies . . .."12

This Article focuses on a key strategy adopted by Wall Street to preserve the universal banking model and its TBTF privileges. The financial industry has promoted the "single point of entry" (SPOE) plan for resolving failures of SIFIs under Title II of DoddFrank. ${ }^{13}$ That plan has attracted the support of U.S. and foreign regulators. ${ }^{14}$ As shown below, Wall Street's SPOE plan would ensure future bailouts for SIFIs and their short-term creditors while imposing the costs of those bailouts on ordinary investors and taxpayers. ${ }^{15}$

Title II of Dodd-Frank establishes the Orderly Liquidation Authority (OLA) to resolve failures of SIFIs. ${ }^{16}$ Under the OLA, the Treasury Secretary may appoint the Federal Deposit Insurance Corporation (FDIC) as receiver for a failing financial company if the failure of that company would have "serious adverse effects on financial stability," and if "no viable private sector alternative is available to prevent" the company's collapse. ${ }^{17}$ Title II requires the FDIC to liquidate a failed SIFI while imposing losses on its shareholders and creditors. ${ }^{18}$ Title II's liquidation-only mandate threatens the TBTF subsidy for SIFIs, ${ }^{19}$ and it therefore presents a

12 Rob Blackwell, Why Citi May Soon Regret Its Big Victory on Capitol Hill, AM. BANKER, Dec. 11, 2014, http://www.americanbanker.com/news/law-regulation/why-citi-may-soon-regr et-its-big-victory-on-capitol-hill-1071636-1.html (quoting my description of Wall Street's motivation for repealing Section 716 of Dodd-Frank).

13 See Martin J. Gruenberg, Acting Chair, FDIC, Remarks at the Federal Reserve Bank of Chicago Bank Structure Conference (May 10, 2012), available at https://www.fdic.gov/news/ news/speeches/archives/2012/spmay1012.html (describing SPOE as "the most promising resolution strategy" for dealing with the failure of a global SIFI).

14 E.g., FDIC \& The BanK of England, Resolving Globally Active, Systemically IMPORTANT, FINANCIAL INSTITUTIONS (2012), available at http://www.bankofengland.co.uk/ publications/Documents/news/2012/nr156.pdf.

15 See infra Part II.c (describing how SPOE would ensure future bailouts for Wall Street creditors and impose losses on ordinary investors and taxpayers).

16 See Dodd-Frank, Pub. L. No. 111-203, § 204(a), 124 Stat. 1376, 1454 (2010) (describing the purpose of the OLF).

17 Dodd-Frank §§ 202(a), 203(b).

18 See infra notes 23-28 and accompanying text (discussing Title II's liquidation-only mandate).

19 See S. ReP. No. 111-176, at 2 (2010). 
direct challenge to the universal banking model. To meet that challenge, Wall Street embraced the SPOE resolution approach.

As explained in Part II of this Article, the FDIC's early rulemakings under Title II indicated that the FDIC would comply with OLA's liquidation-only mandate by breaking up failed SIFIs through structured asset sales. The financial industry, however, responded by advocating the SPOE plan, which would place only the parent holding company of a failed SIFI in receivership while maintaining its operating subsidiaries as going concerns. Shortterm creditors of the holding company and all creditors of the operating subsidiaries would be fully protected. The protected creditors would include uninsured depositors and shadow banking creditors with close connections to Wall Street.

The financial industry's SPOE plan relies on a two-part funding strategy to guarantee continued protection for Wall Street. First, the parent holding company of each SIFI would issue long-term "bail-in" bonds. The FDIC would convert bail-in bonds into equity when a SIFI fails, thereby imposing losses on bail-in bondholders as well as shareholders. SIFIs would market and sell bail-in bonds to non-systemic investors, including mutual funds and pension funds that invest the savings of ordinary individuals.

Second, if write-offs of bail-in bonds are not sufficient to recapitalize a failed SIFI and its operating subsidiaries, SPOE would use the OLF's authority to borrow from Treasury. OLF loans-which are ultimately backstopped by taxpayers-would support the failed SIFI's operating subsidiaries and provide full protection to short-term creditors of the parent holding company and all creditors of the operating subsidiaries. At the end of the OLA process, a new, cleaned-up SIFI would emerge that closely resembles the failed SIFI, except for the losses imposed on the failed SIFI's shareholders and bail-in bondholders. Thus, contrary to Title II's explicit mandate, SPOE would reorganize, rather than liquidate, failed SIFIs and would also guarantee bailouts for Wall Street creditors while imposing the costs of those bailouts on ordinary investors and taxpayers.

Supporters contend that SPOE could provide significant benefits by maintaining the operating subsidiaries of a failed SIFI 
as going concerns and by facilitating cross-border cooperation among domestic and foreign regulators when a global SIFI fails. It is highly doubtful, however, whether those assumed advantages would be realized in fact. Moreover, SPOE's alleged benefits do not justify giving blanket protection to Wall Street creditors at the expense of ordinary investors and taxpayers.

Although U.S. and foreign regulators have not yet formally adopted SPOE, it appears very likely that they will do so. Given that reality, Part III of this Article proposes two reforms to reduce the TBTF subsidy inherent in SPOE. First, SIFIs should pay riskadjusted premiums to prefund the OLF at a level of $\$ 300$ billion or more. The prefunded OLF should be used to cover the costs of resolving a failed SIFI after the FDIC has written off investments by shareholders, holders of subordinated debt, and qualifying holders of bail-in bonds. ${ }^{20}$ Prefunding the OLF would help to protect taxpayers from bearing the costs of resolving failed SIFIs. In addition, risk-adjusted OLF premiums would (1) force SIFIs to internalize at least some of the systemic risks they create and (2) encourage SIFIs to follow more prudent operating strategies and adopt less complex business structures.

As part of their OLF premiums, SIFIs should pay special fees on their uninsured deposits and shadow banking liabilities. Under SPOE, those deposits and liabilities would receive full protection and would enjoy a status similar to insured deposits. The required fees should be comparable to risk-based deposit insurance premiums and should encourage SIFIs to establish more stable, longer-term funding structures.

Second, SIFIs should pay at least half of their compensation to senior executives and other key employees in the form of contingent convertible bonds (CoCos), a type of bail-in debt. Insiders should be required to hold their CoCos, without any

20 To prevent SIFIs from misleading ordinary investors, this Article proposes that SIFIs should be barred from selling bail-in bonds to ordinary individuals, retail mutual funds, or pension funds unless those bonds are explicitly described and marketed as "subordinated debt" that is junior to all general creditor claims. More complex forms of bail-in bonds should be sold only to sophisticated, wealthy individuals and asset managers who do not control funds invested by ordinary individuals. See infra notes 87-90 and accompanying text. 
hedging, for a significant period of time after their employment ends. CoCos would expose insiders to immediate losses if their SIFIs were to fail during their employment or during their postemployment holding period. CoCos would encourage insiders of SIFIs to forgo speculative ventures and adopt sustainable, longterm business strategies that are more closely aligned with the interests of long-term creditors, the FDIC, and taxpayers.

\section{SPOE WOULD PRESERVE TBTF TREATMENT FOR SIFIS AND WALL STREET CREDITORS WHILE IMPOSING LOSSES ON ORDINARY INVESTORS AND TAXPAYERS}

\section{A. IN ITS EARLY RULEMAKINGS UNDER TITLE II, FDIC RECOGNIZED DODD-FRANK'S LIQUIDATION-ONLY MANDATE}

Title II of Dodd-Frank establishes the OLA to provide an orderly process for resolving failed SIFIs. Congress intended that the OLA would provide a "viable alternative" to a "bailout . . . that would expose taxpayers to losses and undermine market discipline."21 Title II's blueprint for resolving failed SIFIs is similar to the FDIC's resolution regime for failed depository institutions. ${ }^{22}$

Title II requires that a financial company placed in an OLA receivership must be liquidated and any losses from the liquidation must be imposed on the company's shareholders and

21 S. REP. NO. 111-176, at 4 (2010).

22 See Richard Scott Carnell, Jonathan R. Macey \& Geoffrey P. Miller, The LaW of FinANCIAL Institutions 485-523 (5th ed. 2013) (describing the FDIC's resolution regime for failed banks); see also Notice of Proposed Rulemaking Implementing Certain Orderly Liquidation Authority Provisions of the Dodd-Frank Wall Street Reform and Consumer Protection Act, 75 Fed. Reg. 64,173, 64,175 (proposed Oct. 19, 2010) (to be codified at 12 C.F.R. pt. 380) [hereinafter FDIC Proposed OLA Rule] ("Parties who are familiar with the liquidation of insured depository institutions under the [Federal Deposit Insurance] Act . . . will recognize many parallel provisions in Title II.”); Orderly Liquidation Authority Provisions of the Dodd-Frank Wall Street Reform and Consumer Protection Act, 76 Fed. Reg. 4207, 4209 (Jan. 25, 2011) (to be codified at 12 C.F.R. pt. 380) [hereinafter FDIC Interim OLA Rule] (restating the premise from the FDIC Proposed OLA Rule regarding "parallel provisions in Title II"). 
creditors. ${ }^{23}$ Section 214(a) declares that "[a]ll financial companies put into receivership under [Title II] shall be liquidated," and "[n]o taxpayer funds shall be used to prevent the liquidation of any financial company under [Title II]." ${ }^{44}$ Thus, Dodd-Frank creates a liquidation-only mandate, as explained in the Senate committee report:

Once a failing financial company is placed under [an OLA receivership], liquidation is the only option; the failing financial company may not be kept open or rehabilitated. The financial company's business operations and assets will be sold off or liquidated, the culpable management of the company will be discharged, shareholders will have their investments wiped out, and unsecured creditors and counterparties will bear losses. ${ }^{25}$

Congress did not want a failed SIFI to emerge from an OLA proceeding as a "rehabilitated" SIFI. ${ }^{26}$ Instead, Congress expected that a failed SIFI would be broken up into smaller companies or its assets would be sold so that the result of an OLA receivership would be a reduced level of systemic risk. ${ }^{27}$ Title II's liquidationonly mandate is a key component of Dodd-Frank's declared purpose "to end "too big to fail" "and "to protect the American taxpayer by ending bailouts." 28

The FDIC recognized the liquidation-only mandate in its early rulemakings under Title II. In late 2010 and early 2011, the FDIC issued proposed and interim rules, which affirmed that "a liquidation under the Dodd-Frank Act is a liquidation of the

\footnotetext{
${ }_{23}$ Dodd-Frank, Pub. L. No. 111-203, § 204(a)(1), 206(2)-(3), 214(a), 124 Stat. 1376, 1454, 1459, 1518 (2010).

${ }^{24} I d . \S 214(\mathrm{a})$.

25 S. REP. No. 111-176, at 4 (emphasis added).

${ }^{26} I d$.

${ }^{27} I d$. at 2,4 .

28 Dodd-Frank, 124 Stat. at 1376 (preamble); see also S. REP. No. 111-176, at 2 (2010) (to accomplish Dodd-Frank's stated goal of ending TBTF, the statute creates "a mechanism to liquidate [SIFIs] should they fail without any losses to the taxpayer").
} 
[financial] company that imposes the losses on its creditors and shareholders... while ensuring that taxpayers bear none of the costs." 29 Both rules stated that the FDIC could establish a bridge financial company (BFC) to "continue key operations, services, and transactions that will maximize the value of [a failed SIFI's] assets and avoid a disorderly collapse in the market place."30 However, the rules also said that a BFC would be employed only as a temporary expedient until the FDIC could arrange an orderly sale of the SIFI's assets to third parties. ${ }^{31}$ The following statements from the rulemakings indicated that the FDIC would use a BFC to accomplish, not circumvent, the liquidation-only mandate:

[T] he FDIC is given broad authority under the DoddFrank Act to operate or liquidate the business, sell the assets, and resolve the liabilities of a covered financial company immediately after its appointment as receiver or as soon as conditions make this appropriate. This authority will enable the FDIC to act immediately to sell assets of the covered financial company to another entity or, if that is not possible, to an FDIC-created bridge financial company while maintaining critical functions ....

... Once the new [BFC]'s operations have stabilized as the market recognizes that it has adequate funding and will continue key operations, the FDIC would move as expeditiously as possible to sell operations and assets back into the private sector. ${ }^{32}$

Thus, the FDIC's early rulemakings were consistent with Title II's liquidation-only mandate. The rulemakings did specify that

\footnotetext{
29 FDIC Proposed OLA Rule, supra note 22, at 64,175; FDIC Interim OLA Rule, supra note 22 , at 4209 .

30 FDIC Proposed OLA Rule, supra note 22, at 64,175; FDIC Interim OLA Rule, supra note 22 , at 4209 .

31 FDIC Proposed OLA Rule, supra note 22, at 64,175; FDIC Interim OLA Rule, supra note 22 , at 4209 .

32 FDIC Proposed OLA Rule, supra note 22, at 64,176; FDIC Interim OLA Rule, supra note 22 , at 4210 .
} 
the FDIC could give preferential treatment to certain short-term creditors to preserve crucial operations of failed SIFIs. In contrast, the FDIC stated that it would never provide such treatment to holders of debt securities with maturities of more than 360 days. $^{33}$ In response to the FDIC's early rulemakings, many critics argued that the FDIC should not favor the same types of short-term Wall Street creditors-including counterparties under derivatives and securities repurchase agreements-whose reckless behavior contributed to the financial crisis. ${ }^{34}$ As discussed below in Parts II.C.1 and III.A.2, the SPOE plan creates similar concerns that the FDIC will give preferential treatment to Wall Street creditors when SIFIs fail.

\section{B. THE FINANCIAL INDUSTRY DEVELOPED SPOE TO EVADE DODD- FRANK'S LIQUIDATION-ONLY MANDATE AND TO GUARANTEE PROTECTION FOR WALL STREET CREDITORS}

During the FDIC's consideration of its early OLA rules, two leading Wall Street trade associations-the Securities Industries and Financial Markets Association (SIFMA) and the Clearing House Association (TCH) - developed a very different strategy for resolving failed SIFIs. Wall Street's strategy-called "recapitalization-within-resolution"-provided a roadmap for reorganizing failed SIFIs instead of liquidating them. ${ }^{35}$ In a

33 FDIC Proposed OLA Rule, supra note 22, at 64,177-78; FDIC Interim OLA Rule, supra note 22, at 4211-12. In July 2011, the FDIC adopted a final rule that reaffirmed its intention to provide preferential treatment to short-term creditors while denying similar treatment to holders of long-term debt securities. See Certain Orderly Liquidation Authority Provisions Under Title II of the Dodd-Frank Wall Street Reform and Consumer Protection Act, 76 Fed. Reg. 41,626, 41,634, 41,644 (July 15, 2011) (codified at 12 C.F.R. pt. 380) [hereinafter FDIC Final OLA Rule].

34 FDIC Final OLA Rule, supra note 33, at 41,627, 41,634 (noting that many commentators objected to the FDIC's plan to favor short-term creditors over long-term creditors); FDIC Interim OLA Rule, supra note 22, at 4211-12 (noting similar objections by commentators to the FDIC's plan); see also Wilmarth, Dodd-Frank, supra note 1, at 998-99 (criticizing the FDIC's plan to provide preferential treatment to short-term creditors because it would "encourage SIFIs to rely even more heavily on vulnerable, short-term funding strategies that led to repeated disasters during the financial crisis").

${ }_{35}$ Randall D. Guynn, Framing the TBTF Problem: The Path to a Solution, in ACross THE Great Divide: New Perspectives on the Financial Crisis 281, 284 n.13 (Martin Neil Baily \& John B. Taylor eds., 2014), available at http://www.hoover.org/sites/default/files/acr 
comment letter submitted to the FDIC in May 2011, SIFMA and TCH argued that "recapitalizations" would be a "more effective" approach for resolving a failed SIFI "during a financial panic than a liquidation of financial assets or the sale of a troubled or insolvent SIFI to a third party." 36

Wall Street's strategy provided the conceptual foundation for SPOE. ${ }^{37}$ In a May 2012 speech, FDIC Chair Martin Gruenberg described SPOE as "the most promising resolution strategy" for dealing with the failure of a global SIFI. ${ }^{38} \mathrm{Mr}$. Gruenberg explained that SPOE would "place the parent [holding] company into receivership and ... pass its assets, principally investments in its subsidiaries, to a newly created bridge holding company. This will allow subsidiaries ... to remain open and avoid the disruption that would likely accompany their closings." 39

In December 2012, the FDIC and the Bank of England (BoE) identified SPOE as a desirable approach for resolving failures of global SIFIs. The FDIC and the BoE argued that SPOE would work well for global SIFIs because, "[b]y taking control of the SIFI at the top of the group, subsidiaries (domestic and foreign) carrying out critical services can remain open and operating, limiting the need for destabilizing insolvency proceedings at the subsidiary level." 40 SPOE could also reduce cross-border complications because the primary supervisor of a failed SIFI would control the resolution process at the "holding company level" while avoiding "foreign insolvency proceedings" for subsidiaries located in other countries. ${ }^{41}$

\footnotetext{
oss-the-great-divide-ch13.pdf (stating that Mr. Guynn, a partner and the head of the Financial Institutions Group at Davis Polk \& Wardwell, helped SIFMA and TCH to develop their "recapitalization-within-resolution" plan for dealing with failed SIFIs).

${ }^{36}$ Letter from Kenneth E. Bentsen, Jr., Exec. Vice President of Pub. Policy \& Advocacy, Sec. Indus. \& Fin. Mkts. Ass'n, \& Mark Zingale, Senior Vice President \& Assoc. Gen. Counsel, The Clearing House Ass'n, to Robert E. Feldman, Exec. Sec'y, FDIC 2 (May 23, 2011), available at http://www.sifma.org/ issues/itemaspx?id=25639.

37 Guynn, supra note 35, at 284 n.13.

38 Gruenberg, supra note 13.

${ }^{39} I d$.

40 FDIC \& THE BANK OF ENGLAND, supra note 14, at 6.

${ }^{41}$ Id. at 11; see also Martin Gruenberg \& Paul Tucker, Op-Ed., When Global Banks Fail, Resolve Them Globally, Fin. TIMEs, Dec. 10, 2012, http://www.ft.com/cms/s/0/fd66d172-3fd4-
} 
While endorsing the SPOE concept, the FDIC and the BoE indicated that the final outcome of a SPOE resolution would be a liquidation of the failed SIFI. The agencies stated that SPOE's "top-down resolution" would be followed by "significant restructuring" that could include "shrinking the [SIFI's] balance sheet, breaking the company up into smaller entities, and/or selling or closing certain operations." 42

In December 2013, the FDIC presented a detailed SPOE proposal in a public call for comments. ${ }^{43}$ Consistent with Wall Street's plan, the FDIC's proposal would put a failed SIFI's parent holding company into an OLA receivership while transferring its operating subsidiaries to a newly-formed BFC. ${ }^{44}$ The FDIC would wipe out the equity interests of the SIFI's shareholders and convert the claims of the SIFI's long-term bondholders into equity interests in the BFC. ${ }^{45}$ The failed SIFI's operating subsidiaries (including banks, securities broker-dealers, and insurance companies) would continue to operate without interruption under the BFC's control, and the rights of creditors of those subsidiaries would not be impaired. 46

After completing an SPOE resolution, the FDIC would approve a "restructuring" plan to transfer the operating subsidiaries from the BFC to one or more successor companies. ${ }^{47}$ The FDIC explained that "restructuring might result in the [BFC] being divided into several companies or parts of entities being sold to third parties," and "the [BFC] might become smaller and less complex." 48 The FDIC's repeated use of the word "might" rather than "will," when discussing asset transfers and sales, indicated a

\footnotetext{
11e2-b0c3-00144feabdc0.html\#axzz3rjlxII58 (explaining that, under SPOE, "subsidiaries (domestic and foreign) would be kept open and operating, thereby limiting contagion effects and cross-border complications").

${ }^{42}$ FDIC \& THE BANK OF ENGLAND, supra note 14, at 9.

${ }_{43}$ Notice of Resolution of Systemically Important Financial Institutions: The Single Point of Entry Strategy, 78 Fed. Reg. 76,614 (Dec. 18, 2013) [hereinafter FDIC SPOE Proposal].

44 Id. at 76,616 .

${ }^{45} I d$.

$46 I d$.

${ }^{47} I d$. at 76,620 .

${ }^{48} I d$. (emphasis added).
} 
possible weakening of the FDIC's commitment to a liquidationonly approach.

Five leading financial industry trade associations enthusiastically endorsed the FDIC's SPOE proposal. ${ }^{49}$ The same groups rejected criticism of the proposal by former Federal Reserve Board Chair Paul Volcker. Mr. Volcker observed that SPOE looked "more like a reorganization under Chapter 11 of the Bankruptcy Code than a liquidation as required by Title II [of Dodd-Frank]." ${ }^{0} \quad \mathrm{I}$ and other commentators agreed with Mr. Volcker's view that SPOE did not appear to be consistent with Title II's liquidation-only mandate. ${ }^{51}$

The Wall Street trade groups claimed that Title II would permit an SPOE strategy that "treats claimants as consistently as possible with how they would have been treated in a successful reorganization under the Bankruptcy Code."52 In fact, however, as

49 See Letter from John Court, Managing Dir. \& Senior Assoc. Gen. Counsel, The Clearing House et al., to Robert E. Feldman, Exec. Sec'y, FDIC (Feb. 18, 2014) [hereinafter 2014 Wall Street SPOE Letter], available at https://www.theclearinghouse.org/ /media/Fi les/Association\%20Documents/20140218\%20Single\%20Point\%20of\%20Entry\%20Comment \%20Letter.pdf (letter from TCH, SIFMA, the American Bankers Association, the Financial Services Roundtable, and the Global Financial Markets Association). TCH had previously issued a report advocating the SPOE strategy. THE ClEARING House, Ending "Too-BIGTO-FAil": Title II of the DodD-Frank ACT AND the APPROACH OF "Single Point of Entry" Private Sector Recapitalization of a Failed Financial Company (2013) [hereinafter 2013 TCH SPOE Report), available at https://www.theclearinghouse.org/ /med ia/Files/Association\%20Documents/20130117\%20Title\%20II\%20and\%20Single\%20Point\%20 of $\% 20$ Entry $\% 20$ White $\% 20$ Paper.pdf.

502014 Wall Street SPOE Letter, supra note 49, at 25 \& n.90 (summarizing Mr. Volcker's argument); see also Joe Adler, Is the FDIC's 'Single-Point' Resolution Plan a Stealth Bailout?, AM. BANKER, Dec. 13, 2013, available at 2013 WLNR 31174108 (quoting Mr. Volcker's opinion that SPOE “'doesn't sound like a liquidation'”).

51 See, e.g., Adler, supra note 50 (quoting my statement that "[SPOE] doesn't look like a liquidation. It looks like a ... reorganization in which the systemically important financial institution survives to fight another day."); Who Is Too Big to Fail: Does Title II of the DoddFrank Act Enshrine Taxpayer-Funded Bailouts?: Hearing Before the Subcomm. on Oversight \& Investigations of the H. Comm. on Fin. Servs., 113th Cong. 3 (2013) (statement of David A. Skeel, Jr.), http://financialservices.house.gov/uploadedfiles/hhrg-113-ba09-wstate-dskeeel-201 30515.pdf ("[A]lthough Title II explicitly requires that its provisions be used for liquidation, [single point of entry] is essentially a reorganization. It thus stands in tension with the explicit requirements of Title II.”).

${ }^{52} 2014$ Wall Street SPOE Letter, supra note 49, at 26 (emphasis added). The trade groups did not cite any provision of Title II that explicitly requires treatment for creditors similar to a reorganization under Chapter 11 of the Bankruptcy Code. The groups did, 
the groups acknowledged, Title II only requires that creditors receive "at least as much value in satisfaction of their claims as they would have received in a liquidation under Chapter 7 of the Bankruptcy Code." ${ }^{3}$ To bolster their argument for a reorganization strategy, the Wall Street groups asserted that dissolving a failed SIFI's parent holding company would be sufficient to satisfy the liquidation-only mandate. ${ }^{54}$ They also contended that Title II does not require any restructuring of operating subsidiaries after they are transferred to a BFC. ${ }^{55}$ Other Wall Street supporters maintained that Title II would allow a BFC and its operating subsidiaries to emerge intact as a "new financial holding company" following an SPOE resolution. ${ }^{56}$

Thus, Wall Street's SPOE plan contemplates little or no restructuring at the holding company level or the subsidiary level after the FDIC has transferred operating subsidiaries from a failed SIFI's parent holding company to a BFC. Wall Street obviously prefers a reorganization strategy that would convert a failed SIFI into a new, cleaned-up SIFI with a minimum of structural

however, assert that a "duty" to provide such treatment could be "implied" from Title II's overall purpose to "avoid or mitigate" the potential for "serious adverse effects on financial stability in the United States." Id. at 26 n.97.

${ }_{53} I d$. at 26 (citing Dodd-Frank $\left.\S \S 210(\mathrm{a})(7)(\mathrm{B}),(\mathrm{d})(2)(\mathrm{B})\right)$.

${ }^{54} I d$. at 25 .

55 Id. at 25, 27; see also Guynn, supra note 35, at 291 ("[T] applies to the financial company that is actually put into a Title II receivership. Under the SPOE strategy, only the parent would be put into such a receivership.”).

56 Guynn, supra note 35, at 295 ("In the final step, the old bridge company becomes a new financial holding company, fully in the private sector."). The Bipartisan Policy Center, a think tank that is widely viewed as a supporter of Wall Street, see infra note 62 and accompanying text, has advocated the same outcome. JOHN F. BOVENZI ET AL., BIPARTISAN Policy Ctr., Too Big to Fail: The Path to a Solution: A Report of the Failure Resolution Task Force of the Financial Regulatory ReForm Initiative of the BIPARTISAN POLICY CENTER 31 (2013) [hereinafter 2013 BPC SPOE Report], available at http://bipartisanpolicy.org/library/too-big-fail-path-solution-525 (stating that, at the end of an SPOE resolution, "the bridge holding company would be converted into a normal stateor federally chartered corporation"); $i d$. at 30 fig.7 (showing graphically how the BFC would be converted into a new financial holding company). The principal authors of the 2013 BPC SPOE Report were John Bovenzi (partner in the Oliver Wyman financial consulting firm), Randall Guynn (head of Davis Polk's financial institutions practice and originator of the "recapitalization-within-resolution" concept), see supra note 35, and Thomas Jackson (a leading bankruptcy law scholar). 2013 BPC SPOE Report, supra, at 82. 
changes. ${ }^{57}$ The extent to which the FDIC agrees with Wall Street's strategy remains unclear. ${ }^{58}$ The FDIC's SPOE proposal stated, however, that SPOE resolutions would use some of the same claims procedures and accounting principles as are used in Chapter 11 reorganizations under the Bankruptcy Code. ${ }^{59}$

${ }^{57}$ Guynn, supra note 35, at 295-96; 2013 BPC SPOE Report, supra note 56, at 30-31. In her comment letter on the FDIC's SPOE proposal, former FDIC Chair Sheila Bair warned that,

without further progress under Title I [of Dodd-Frank] to require U.S. SIFIs to simplify and rationalize their legal structures, the most likely outcome of the SPOE approach will be to replace one systemic firm with another.... [T] his new firm ... could still have the same name, many of the same employees, and pose the same external risks to the system. Adler, supra note 50, at 3 (quoting letter from Ms. Bair dated Feb. 18, 2014).

The financial industry has also advocated the enactment of a new "Chapter 14" of the Bankruptcy Code, which would authorize federal bankruptcy courts to use an SPOE approach for reorganizing insolvent financial holding companies. As I have described elsewhere, the financial industry's "Chapter 14" proposal contemplates even greater benefits for SIFIs and their executives and Wall Street creditors than those parties would receive in an SPOE resolution under Title II of Dodd-Frank. See Arthur E. Wilmarth, Jr., The Financial Industry's Bankruptcy Plan for Resolving Failed Megabanks Would Give Unwarranted Benefits to Their Executives and Wall Street Creditors, CLS Blue SkY Blog (Nov. 3, 2015), http://clsbluesky.law.columbia.edu/2015/11/03/the-financial-industrys-bankruptcy-plan-for-res olving-failed-megabanks-would-give-unwarranted-benefits-to-their-executives-and-wall-streetcreditors/.

58 In his May 2012 speech, FDIC Chair Martin Gruenberg described SPOE as a resolution strategy under which the FDIC takes control of the failed [SIFI] at the parent holding company level and establishes a bridge holding company as an interim step in the conversion of the failed [SIFI] into a new well-capitalized private sector entity. We believe this strategy holds the best possibility of ... producing a new, viable private sector company out of the process.

Gruenberg, supra note 13. Those remarks appear to be generally consistent with Wall Street's reorganization strategy. In another speech three years later, Mr. Gruenberg stated that "the resolution process [under SPOE] would end with the termination of the bridge financial company]" as well as "the wind-down of the $[\mathrm{BFC}]$ in a way that minimizes systemic disruption." Martin J. Gruenberg, Chair, FDIC, A Progress Report on the Resolution of Systemically Important Financial Institutions, Address to the Peterson Instit. for Int'l Econ. (May 12, 2015), available at https://www.fdic.gov/news/news/speeches/spmay 1215.html. Mr. Gruenberg's 2015 speech could be viewed as departing to some extent from Wall Street's reorganization strategy.

59 FDIC SPOE Proposal, supra note 43, at 76,618 ("[T] he FDIC intends to adapt certain claims forms and practices applicable to a Chapter 11 proceeding under the Bankruptcy code."); see also id. at 76,619 (stating that the FDIC's SPOE resolution process would follow the "fresh start model" for accounting treatment that is "generally applied to companies emerging from bankruptcy under Chapter 11"). 


\section{WALL STREET'S SPOE STRATEGY WOULD ENSURE FUTURE BAILOUTS FOR WALL STREET CREDITORS AND IMPOSE LOSSES ON ORDINARY INVESTORS AND TAXPAYERS}

1. SPOE Would Protect Wall Street Creditors of Failed SIFIs. As shown in the preceding section, Wall Street's SPOE plan would allow a failed SIFI to be reorganized rather than liquidated, and it would enable the SIFI's successor holding company and former operating subsidiaries to emerge intact as a new SIFI. ${ }^{60}$ Wall Street's version of SPOE would also maintain the operating subsidiaries during the resolution process and protect their creditors from any losses. ${ }^{61}$ In a May 2013 report, the Bipartisan Policy Center (BPC) - a think tank that receives significant funding from the financial industry and generally supports policies favorable to Wall Street ${ }^{62}$ - highlighted those outcomes as key virtues of SPOE. ${ }^{63}$

Wall Street's SPOE strategy strongly resembles the expedited "Section 363" transactions that federal officials used to reorganize Chrysler and General Motors (GM) under Chapter 11 of the Bankruptcy Code. ${ }^{64}$ In the Chrysler case-on which the

60 Guynn, supra note 35, at 290-91, 295-96; 2013 BPC SPOE Report, supra note 56, at 26-28, 31-32.

61 Guynn, supra note 35, at 295-96; 2013 BPC SPOE Report, supra note 56, at 27-28.

62 See Public Citizen, Made in the Shade: An Examination of Whether the Bipartisan Policy Center Is Truly Neutral 6-7 (2013), available at http://www.citizen. org/documents/biparisan-policy-center-neutrality-report.pdf (reporting that the American Bankers Association and Citigroup were "major contributors" to BPC in 2012, and describing BPC's financial regulatory task force as an "industry dominated panel" because most members had "clear ties to large banks"); Simon Johnson, The Dark Side of Bipartisanship, N.Y. TIMES ECONOMIX BLOG, Oct. 25, 2012, http://economix.blogs.nytimes.c om/2012/10/25/the-dark-side-of-bipartisanship/?_r=1 ("[T]he Bipartisan Policy Center seems likely to side with industry lobby groups on all substantive questions."); see also BIPARTISAN POLICY CTR., 2014: ANNUAL REPORT 54-55 (2015), available at http://bipartisanpol icy.org/wp-content/uploads/2015/05/BPC-2014-Annual-Report.pdf (listing the American Bankers Association, American Express, Bank of America, BlackRock, Citigroup, Credit Suisse, Fidelity Investments, Financial Services Forum, Financial Services Roundtable, Goldman Sachs, Institute of International Bankers, MetLife, PNC Financial, Prudential, The Clearing House, and Zurich Insurance Group among BPC's corporate donors).

632013 BPC SPOE Report, supra note 56, at 23-32, 63-70.

64 Id. at 31, 33-34; see also David A. Skeel Jr., Single Point of Entry and the Bankruptcy Alternative 15 (Univ. of Pa. Law Sch. Inst. for Law \& Econ., Research Paper No. 14-10, 2014), available at http://ssrn.com/abstract=2408544 (observing that SPOE "bears a striking 
subsequent GM deal was modeled-the federal government (1) created a shell company (similar to a BFC), (2) provided massive funding to finance the shell company's purchase of substantially all of Chrysler's assets, and (3) arranged for the shell companywhich became the "new" Chrysler-to assume responsibility for claims held by favored creditors (including trade creditors and beneficiaries under Chrysler's pension and health care plans). Meanwhile, the claims of disfavored creditors (including secured bondholders, terminated dealers, and customers with product liability claims) were left behind in the bankruptcy estate of "old" Chrysler. ${ }^{65}$ As Mark Roe and David Skeel pointed out, the Chrysler reorganization was highly controversial, and " $t]$ he unevenness of the compensation to prior creditors raised considerable concerns in capital markets." 66

Like the Chrysler transaction, Wall Street's SPOE plan would disfavor long-term bondholders of a failed SIFI's parent holding company while providing full protection to short-term creditors of the holding company and all creditors of its operating subsidiaries. The favored creditors would include uninsured depositors, holders of commercial paper, and counterparties under derivatives and securities repurchase agreements, many of whom are institutional investors with close connections to Wall Street. ${ }^{67}$

resemblance" to the federal government's restructuring of Chrysler and General Motors); Stephen J. Lubben, OLA After Single Point of Entry: Has Anything Changed?, in AN UNFINISHED Mission: MAKING WALL STREet WorK FOR Us 13, 13 (Mike Konczal \& Marcus Stanley, Americans for Fin. Reform \& the Roosevelt Institute eds., 2013), available at http:// rooseveltinstitute.org/wp-content/uploads/2015/11/Unfinished_Mission_2013.pdf (noting that SPOE uses "a process that is very much like that used in ' 363 sales' under chapter 11, widely publicized by the automotive bankruptcy cases").

65 Mark J. Roe \& David Skeel, Assessing the Chrysler Bankruptcy, 108 Mich. L. REv. 727, 729-34, 765 (2010); Skeel, supra note 64, at 15; see also Adam Levitin, Single-Point-of-Entry: No Bank Left Behind, CREDIT SLIPS (Aug. 31, 2014, 6:42 PM), http://www.creditslips.org/cred itslips/2014/08/single-point-of-entry-no-bank-left-behind.html (explaining that, under SPOE, as with the Chrysler and GM bankruptcies, "[t]he good assets and favored liabilities are transferred to a new, government-backed entity, while the disfavored liabilities remain with the old, liquidating entity").

${ }_{66}$ Roe \& Skeel, supra note 65, at 770. For a contrasting and more favorable assessment of the Chrysler and GM bankruptcies, see Stephen J. Lubben, No Big Deal: The GM and Chrysler Cases in Context, 83 AM. BANKR. L.J. 531 (2009).

672013 BPC SPOE Report, supra note 56, at 28, 31; see also Levitin, supra note 65 (stating that under SPOE, "all of the derivative counterparties, all of the commercial paper 
2. Wall Street's Funding Plan for SPOE Resolutions Would Impose Losses on Ordinary Investors and Taxpayers. Wall Street's SPOE strategy relies on a two-part funding plan that would protect Wall Street creditors at the expense of ordinary investors and taxpayers. The first major funding source would be long-term bail-in bonds issued by parent holding companies of SIFIs. When a SIFI fails, the bail-in debt would be converted into equity to capitalize the newly-formed BFC, to support the SIFI's operating subsidiaries, and to protect the creditors of those subsidiaries from any losses. ${ }^{68}$

The Financial Stability Board (FSB) recently proposed that global systemically important banks (G-SIBs) should be required to issue long-term debt to provide "total loss-absorbing capacity" (TLAC) for their resolution if they fail. ${ }^{69}$ The FSB's TLAC proposal would compel G-SIBs (the largest global SIFIs) to issue long-term, unsecured debt that could be either written off or converted into equity. The proceeds from write-downs and conversions of bail-in debt would be used to protect depositors and other favored short-term creditors, including counterparties under derivatives and securities repurchase agreements. ${ }^{70} \mathrm{~A}$ former

creditors, all of the repo counterparties, and all of the securities lending counterparties get bailed out").

68 Guynn, supra note 35, at 289-90, 292, 295-96; 2013 BPC SPOE Report, supra note 56, at 26-28, 31-32; 2013 TCH SPOE Report, supra note 49, at 6-7, 24-26; see also Charles Goodhart \& Emilios Avgouleas, A Critical Evaluation of Bail-ins as Bank Recapitalisation Mechanisms 3-5, 7-9 (Ctr. for Econ. Policy, Research Discussion Paper 10065, 2014), available at http://ssrn.com/abstract=2478647 (describing the "bail-in" debt strategy advocated by SPOE supporters); Michael Krimminger, Shadows and Mirrors: The Role of Debt in the Developing Resolution Strategies in the U.S., U.K., and European Union 10-14, 20 (Dec. 30, 2014) (unpublished manuscript), available at http://ssrn.com/abstract=2560982 (outlining the "bailin" debt strategy).

69 Adequacy of Loss-Absorbing Capacity of Global Systemically Important Banks in Resolution: Consultative Document, Fin. STABILITY BD. (Nov. 10, 2014) [hereinafter 2014 FSB TLAC Proposal], http://www.financialstabilityboard.org/wp-content/uploads/TLAC-Con doc-6-Nov-2014-FINAL.pdf; see also Krimminger, supra note 68, at 20-25 (describing the FSB's TLAC proposal); 2014 Update of List of Global Systemically Important Banks (GSIBs), FIN. STABILITY BD. (Nov. 6, 2014), http://www.financialstabilityboard.org/2014/11/20 14-update-of-list-of-global-systemically-important-banks (designating $30 \mathrm{G}$-SIBs, including eight G-SIBs headquartered in the U.S.).

70 See Krimminger, supra note 68, at 20-25 (discussing the use of bail-in debt to satisfy the FSB's proposed TLAC requirement); see also 2014 FSB TLAC Proposal, supra note 69, 
FDIC General Counsel remarked that the FSB's "TLAC proposal was developed in the context of [the SPOE] strategy" and was "designed to maintain systemically important operations in subsidiaries" of failed G-SIBs. ${ }^{71}$

The FSB's TLAC proposal would force global SIFIs to issue hundreds of billions of dollars of bail-in debt. ${ }^{72}$ SIFIs would face significant challenges in finding buyers for that debt. Regulators agree that SIFIs should not sell bail-in bonds to other SIFIs because cross-holdings of bail-in debt among large financial institutions would increase the risks of contagion during a crisis. ${ }^{73}$

SIFIs could potentially sell bail-in debt to hedge funds and private equity funds. Many of those funds, however, borrow large amounts from SIFIs. Consequently, regulators might not be able to impose bail-in debt losses on hedge funds or private equity funds during a crisis due to concerns about their ability to repay their loans to SIFIs. ${ }^{74}$

at 6-8, 13-20 (explaining the TLAC proposal). The FSB issued its final international TLAC standard in November 2015, after the manuscript for this article had been completed. See Press Release, Fin. Stability Bd., FSB Issues Final Total Loss-Absorbing Capacity Standard for Global Systemically Important Banks (Nov. 9, 2015), available at http://www.financialst abilityboard.org/2015/11/tlac-press-release/.

${ }^{71}$ Krimminger, supra note 68, at 23; see also id. at 1 n.1, 23 (noting that the author, a former FDIC General Counsel, "participated in the original discussions leading to the suggestion of the SPOE approach").

72 See John Glover, Bank Holding Company Bonds Fray as Traders Fret Over Risk, BLOOMBERG, Nov. 27, 2014, http://www.bloomberg.com/news/articles/2014-11-27/bank-holdi ng-company-bonds-fray-as-traders-fret-over-risk (reporting that G-SIBs already held "about $\$ 650$ billion of loss-absorbing bonds" but "[t]hat amount may have to almost double to meet FSB requirements"); Ben Moshinsky, FSB's Too-Big-to-Fail Bank Fix Seen Dragging on Economy, BloOMBERG, Feb. 2, 2015, http://www.bloomberg.com/news/articles/2015-02-03/fb s-s-too-big-to-fail-fix-seen-dragging-on-economy (citing a Standard \& Poor's estimate that the $30 \mathrm{G}-\mathrm{SIBs}$ designated by FSB would need to issue about $\$ 500$ billion of additional TLAC-eligible debt to meet the FSB's proposed requirement).

${ }_{73}$ Paul Tucker, Deputy Governor, Bank of Eng., Resolution and the Future of Finance, Speech at the INSOL International World Congress (May 20, 2013), available at http://www. bankofengland.co.uk/publications/Documents/speeches/2013/speech658.pdf; see also 2014 FSB TLAC Proposal, supra note 69, at 12 ("To reduce the potential for a G-SIB resolution to spread contagion into the global banking system, it will be important to strongly disincentivise internationally active banks from holding TLAC issued by G-SIBs.").

${ }^{74}$ Avinash Persaud, Bail-ins Are No Better Than Fool's Gold, Fin. Times, Oct. 21, 2013, http://www.ft.com/intl/cms/s/0/686dfaa4-27a7-11e3-8feb-00144feab7de.html. 
Regulators are therefore likely to encourage SIFIs to sell bail-in debt to non-systemic investors, including pension funds and mutual funds. ${ }^{75}$ Major banks have already sold about $\$ 300$ billion of contingent convertible bonds (CoCos). ${ }^{76}$ CoCos are bail-in bonds that automatically convert to equity upon the occurrence of one or more designated events (such as the issuer's insolvency). ${ }^{77}$ Banks have successfully marketed CoCos to asset managers because of a "hunt for yield" in a global debt market characterized by "ultra-low interest rates." 78

Analysts have expressed growing concerns about the complexity of CoCos and other bail-in bonds as well as the difficulty of estimating losses that investors might suffer from bond writedowns or conversions into equity. ${ }^{79}$ In 2014 the U.K.'s Financial Conduct Authority (FCA) barred U.K. banks from selling CoCos directly to retail investors due to their "complex" and "highly

75 Id.; John Glover, Nicholas Comfort \& Ben Moshinsky, Bank-Debt Buyers Won't Sleep Easily at Night on Write-Down Bonds, 104 Bloomberg BNA BANkING ReP. 337 (2015); see also Leonid Bershidsky, Hunt for Exotic Yields Is Dangerous, BloomBerg View, Apr. 24, 2014, http://www.bloombergview.com/articles/2014-04-24/hunt-for-exotic-yields-is-dangerous ("The CoCo idea is fashionable among regulators ....").

${ }^{76}$ Christopher Thompson, Chinese Banks Issue Most Coco Bonds, Fin. Times, Feb. 11, 2015, http://www.ft.com/intl/cms/s/0/5a99b804-b135-11e4-9331-00144feab7de.html\#axzz3s2aMHHSL ("Banks have issued $\$ 288 \mathrm{bn}$ of cocos since the asset claim first appeared in 2009 . ...").

77 See generally Stefan Avdjiev, Anastasia Kartasheva \& Bilyana Bogdanova, CoCos: A Primer, 2013 BIS Q. REV. 43, available at http://ssrn.com/abstract=2326334 (providing an overview of CoCos).

78 James Shotter, Deutsche Sells 10-Year Debt with 2.75\% Coupon, Fin. TIMES, Feb. 9, 2015, http://www.ft.com/intl/cms/s/0/a1af5768-b076-11e4-9b8e-00144feab7de.html; see also Christopher Thompson, Bank Debt Issuance Doubles to Record Levels, Fin. TIMES, Jan. 19, 2015, http://www. ft.com/intl/cms/S/0/e64de99a-9ffd-11e4-aa89-00144feab7de.html (describing a strong demand for CoCos due to a "voracious investor appetite for yield"); Bershidsky, supra note 75 ("Asset managers have bought more than 60 percent of seven recent issues [of CoCos] by big banks" in a market where investors were "[t]ortured by low interest rates ....").

79 See Bershidsky, supra note 75 ("[I]nvestors may be underestimating the risks [of CoCos,]. . the scale of which is hard to pin down.”); Glover, Comfort \& Moshinsky, supra note 75, at 337-38 (describing the uncertainty and risks inherent in bail-in bonds); Frances Schwartzkopff, Bank Bail-In Extras Alarm Investors as Danske Eyes Debt, BlOOMBERG, Dec. 8, 2014, http://www.bloomberg.com/news/articles/2014-12-07-bank/bail-in-extras-alarm-invest ors-as-danske-explores-new-debt (discussing concerns with the complexity and risks of bail-in bonds). 
risky" features. ${ }^{80}$ The FCA and other regulators, however, have allowed SIFIs to sell CoCos and other bail-in bonds to pension funds and mutual funds that serve retail investors (retail mutual funds), even though ordinary individuals would ultimately bear any losses on those bonds. ${ }^{81}$

Selling bail-in debt to pension funds and retail mutual funds would simply shift some of the costs of resolving failed SIFIs from taxpayers to individual savers while protecting favored Wall Street creditors. ${ }^{82}$ In his recent testimony before a House of Lords subcommittee, HSBC chairman Douglas Flint argued that society must bear the costs of resolving failed SIFIs, and he noted that bail-in debt provides a method for "distributing the burden of failure" from taxpayers to pensioners and retail investors. ${ }^{83} \mathrm{Mr}$. Flint asserted, "At the end of the day, the burden of failure rests with society. Whether you take it out of society's future income through taxation or whether you take it out through their pensions or savings, society is bearing the cost." 84

Mr. Flint's remarkable statement exposes the assumption of megabank insiders that society-including taxpayers, pensioners, and retail investors-must pay for the costs of resolving failed

\footnotetext{
80 Jenny Anderson, British Watchdog Curbs High-Yield Bonds Called CoCos for Small Investors, N.Y. TIMES, Aug. 5, 2014, http://dealbook.nytimes.com/2014/08/05/british-watchd og-curbs-high-yield-bonds-called-cocos-for-small-investors (quoting Christopher Woolard, the FCA's director of policy, risk and research).

81 See Jeremy C. Jennings-Mares, CoCo No-Go for Ordinary Joe, MoRRISON \& FoERSTER 2 (Aug. 11, 2014), http://www.mofo.com/ /media/Files/ClientAlert/2014/08/140811CoCoNoGofor OrdinaryJoe.pdf (explaining that the FCA's ban on sales of CoCos to ordinary retail investors would not prohibit sales of $\mathrm{CoCos}$ to pension funds and "regulated collective investment scheme[s]" in which ordinary individuals hold "beneficial interests"); see also Bershidsky, supra note 75 (contending that regulators are likely to place retail investors at risk by allowing asset managers to buy CoCos).

82 See Goodhart \& Avgouleas, supra note 68, at 24 ("[S]hifting from bail-out to bail-in will ... primarily transfer the burden of loss from one set of domestic players, the taxpayers, to another, the pensioners and savers.").

83 U.K. House of Lords, Review of the EU Financial Regulatory Framework Before SubComm. A (Econ. \& Fin. Affairs) of the Select Comm. on the Eur. Union of the U.K. House of Lords (Oct. 21, 2014) (testimony of Douglas Flint) [hereinafter 2014 Flint Testimony], available at http://data.parliament.uk/writtenevidence/committeeevidence.svc/evidencedocu ment/eu-sub-a-economic-and-financial-affairs-committee/review-of-the-eu-financial-regulat ory-framework/oral/14795.html.

${ }^{84}$ Id. (emphasis added).
} 
SIFIs. ${ }^{85}$ He did not mention the possibility that SIFIs or their insiders might bear any responsibility for excessive risk-taking. Mr. Flint's assertion reflects the prevailing attitude on Wall Street and in the City of London before, during, and after the financial crisis: SIFIs and their insiders should retain their profits and bonuses from high-risk activities while governments and ordinary citizens must bear the losses. ${ }^{86}$

As a matter of social equity, "pushing pensioners [and retail investors] under the bus" to save SIFIs and their Wall Street creditors is no more palatable than relying on taxpayers to finance bailouts. ${ }^{87}$ Pensioners and retail investors do not have a superior ability, compared with taxpayers, to evaluate the risks of SIFIs or to bear the financial burden of bailing out SIFIs and their favored creditors. ${ }^{88}$ Accordingly, regulators should prohibit SIFIs from selling bail-in bonds to ordinary individuals, retail mutual funds, and pension funds unless those bonds are explicitly marketed and sold as "subordinated debt" that is junior to the claims of all general creditors. SIFIs should be barred from selling bonds to such investors that are designated as "senior" to subordinated debt but contain high-risk, bail-in features. SIFIs are already concocting such instruments for the purpose of selling bail-in debt with lower interest rates than subordinated debt. ${ }^{89}$

\footnotetext{
85 See James Titcomb, Mark Carney: No More Bank Bail-Outs, DAILY TelEGRAPH, Nov. 10, 2014, http://www.telegraph.co.uk/finance/newsbysector/banksandfinance/11220192/Mark-Car ney-No-more-bank-bail-outs.html ("Douglas Flint, the chairman of HSBC, has said that bail-in rules will still mean the public being on the hook for banks.").

86 Simon Johnson \& James Kwak, 13 Bankers: The Wall Street Takeover and the NeXT Financial Meltdown 12 (2010) ("The basic, massive subsidy scheme [for SIFIs] remains unchanged: when times are good, the banks keep the upside as executive and trader compensation; when times are bad and potential crisis looms, the government picks up the bill."); see also Wilmarth, Blind Eye, supra note 1, at 1394-97 (explaining how major U.K. banks pushed for deregulation and "light touch" supervision, which ultimately led to a massive crisis in which "U.K. authorities were forced to bail out four of the nine largest U.K. banks"). See generally JoHNSON \& KWAK, supra, at 10-12, 133-34, 150-74, 178-82 (describing the prevailing views on Wall Street before and during the financial crisis).

87 Persaud, supra note 74; accord Goodhart \& Avgouleas, supra note 68, at 24.

88 Bershidsky, supra note 75; Goodhart \& Avgouleas, supra note 68, at 24-25; Persaud, supra note 74 .

89 Christopher Thompson, Banks Engineer Lower-Cost Risk Capital, Fin. Times, Feb. 2, 2015, http://www.ft.com/intl/cms/s/0/7256ad46-aae4-11e4-81bc-00144feab7de.html\#axzz3s2
} 
Prohibiting SIFIs from selling bail-in bonds, except for subordinated debt, to ordinary investors would (1) greatly reduce the risk of misleading those investors about the risks of bail-in bonds and (2) require SIFIs to pay higher interest rates that would more fairly compensate ordinary investors for the extraordinary risks inherent in bail-in debt. SIFIs should sell more complex bailin bonds only to sophisticated, wealthy individuals and to institutional investors who do not manage funds for ordinary individuals. The foregoing restrictions might persuade SIFIs to issue greater amounts of common stock and non-cumulative perpetual preferred stock in order to satisfy the FSB's proposed TLAC requirement. ${ }^{90}$ That would be a highly desirable outcome. Shareholders' equity provides the most stable and durable source of funding for financial institutions because shareholders cannot force a SIFI to redeem their investments and cannot declare a default if a SIFI is forced to suspend dividends to conserve its capital. ${ }^{91}$

Wall Street's SPOE plan relies on the Orderly Liquidation Fund (OLF) as its second major funding source and ultimate backstop. If the assets and bail-in bonds of a failed SIFI's holding company are not sufficient to capitalize the BFC and to cover the losses of its operating subsidiaries, the FDIC would use the OLF to fill the gap. ${ }^{92}$ Dodd-Frank does not establish a prefunding mechanism for the OLF, and the OLF therefore has a zero balance. ${ }^{93}$ The FDIC, however, can obtain immediate funding from the OLF by

a MHHSL (reporting that SIFIs "are looking for clever ways to lower the cost" of bail-in debt by creating new types of bonds that "would incur losses in the event of a bank default but pay out less in interest to creditors than dearer, existing subordinated bonds").

90 See Glover, Comfort \& Moshinsky, supra note 75 (describing the challenges faced by megabanks in finding enough investors to purchase the bail-in bonds the banks must sell to satisfy the FSB's proposed TLAC requirement).

91 See CARNELl, MACEY \& MilleR, supra note 22, at 223-24 (describing common stock and non-cumulative perpetual preferred stock). For a comprehensive analysis demonstrating that regulators should require megabanks to operate with much lower levels of leverage and to fund their operations with much higher levels of equity capital, see generally ANAT ADMATI \& MARTIN HellWig, The BANKeR's NEW Clothes: WHAT's WRONG WITH BANKING AND WHAT TO Do ABouT IT (2013).

92 See Dodd-Frank, Pub. No. 111-203, § 210(n), 124 Stat. 1376, 1506 (2010) (establishing the OLF to finance liquidations of failed SIFIs under the OLA).

${ }^{93}$ See infra notes 126-28 and accompanying text. 
borrowing from Treasury a total amount of up to $10 \%$ of a failed SIFI's assets during the first thirty days after the FDIC has been appointed as receiver, plus $90 \%$ of the "fair value" of the failed SIFI's assets that become available to repay the OLF loan after the first thirty days. ${ }^{94}$

The FDIC's ability to borrow from Treasury provides "huge amounts of funding" to protect favored creditors of SIFIs and their operating subsidiaries. ${ }^{95}$ The fair value standard gives the FDIC considerable leeway in determining how much it can borrow from Treasury because it does not require the FDIC to use current market prices in valuing a failed SIFI's assets. ${ }^{96}$ Moreover, as David Skeel has pointed out, Treasury loans for OLA resolutions will have "generous" terms, including interest rates that "will almost certainly be less than the penalty rate of interest called for in traditional lender-of-last-resort lending." 97

The FDIC must ordinarily repay an OLF loan from Treasury within five years. ${ }^{98}$ If the proceeds from resolving a failed SIFI are insufficient to repay the loan, the FDIC must impose retroactive assessments on large financial institutions to recover the difference. ${ }^{99}$ Treasury may, however, extend the FDIC's repayment period indefinitely if such action is necessary "to avoid a serious adverse effect on the financial system of the United States."100 During a future systemic crisis, it is likely that the

\footnotetext{
94 Dodd-Frank $\S 210(n)(5)$, (6). In order to borrow funds from Treasury to finance a resolution of a failed SIFI, the FDIC must enter into a repayment agreement with Treasury after consulting with the Senate Committee on Banking, Housing, and Urban Affairs and the House Committee on Financial Services. Id. § 210(n)(9).

95 Skeel, supra note 64, at 14, 17.

96 Wilmarth, Dodd-Frank, supra note 1, at 999.

97 Skeel, supra note 64, at 14 (explaining that §210(n)(5)(C) of Dodd-Frank authorizes Treasury to charge interest rates on OLF loans based on "the average interest rates for a basket of corporate bonds" of comparable maturity); see also Examining How the Dodd-Frank Act Could Result in More Taxpayer-Funded Bailouts: Hearing Before the H. Comm. on Fin. Servs., 113th Cong. 72, 82 (2013) (statement of Richard W. Fisher, President and Chief Exec. Officer, Fed. Reserve Bank of Dallas), available at http://www.gpo.gov/fdsys/pkg/CHRG-113hh rg81769/pdf/CHRG-113hhrg81769.pdf ("Call it whatever you wish, but this is taxpayer funding [for SPOE resolutions] at far-below-market rates.”).

98 Dodd-Frank $\S$ 210(n)(9)(B), (o)(1)(B).

99 Wilmarth, Dodd-Frank, supra note 1, at 1015.

100 Dodd-Frank $\S \S 210(n)(9)(B), 210(o)(1)(B),(C)$.
} 
FDIC would request, and Treasury would approve, a prolonged extension of the OLF repayment schedule, thereby postponing the FDIC's duty to impose assessments on surviving SIFIs. During such a crisis - as was certainly true in 2008-many SIFIs would not be strong enough to bear the additional burden of paying large assessments, as they would be exposed to many of the same risks that caused their peers to fail. Accordingly, OLF loans for SPOE resolutions would frequently be extended far beyond the standard five-year term and would represent lengthy, taxpayer-funded bridge loans for the benefit of protected SIFI creditors. ${ }^{101}$

Thus, Wall Street's SPOE plan would provide "a stealth bailout" for favored creditors of failed SIFIs and their operating subsidiaries because bail-in bondholders (i.e., ordinary investors) and OLF loans (i.e., taxpayers) would bear the burden of protecting those creditors. ${ }^{102}$ Many favored creditors of failed SIFIs and their operating subsidiaries would be institutional investors with close connections to Wall Street, including holders of uninsured deposits, commercial paper, securities repurchase agreements, and other shadow banking liabilities. ${ }^{103}$ As Adam Levitin has observed, SPOE "ensures that Wall Street [creditors] will be rescued if a SIFI goes down."104

When the FDIC released its SPOE proposal, FDIC Vice Chair Thomas Hoenig warned that OLF funding would give SIFIs a significant cost of funding advantage, especially during future financial disruptions:

In times of financial stress, the knowledge that operating units [of failed SIFIs] will be provided funding to meet liquidity demands could serve to

\footnotetext{
101 Wilmarth, Dodd-Frank, supra note 1, at 1020-21.

102 Lubben, supra note 64, at 16.

103 See Guynn, supra note 35, at 295-96 (describing how SPOE would provide preferential treatment for holders of short-term unsecured debt over long-term debtholders); 2013 BPC SPOE Report, supra note 56, at 27-28, 31, 66, 68-69 (same); infra notes 139-55 and accompanying text (describing the heavy reliance of SIFIs on short-term debt funding provided by Wall Street investors, including uninsured depositors and holders of commercial paper, securities repurchase agreements, and other shadow banking liabilities).

${ }^{104}$ Levitin, supra note 65.
} 
encourage corporate treasurers and others to place their funds with SIFIs' operating subsidiaries over other financial firms for whom such assurances are unavailable. Therefore, this assumption and access to funding provides SIFIs a significant competitive advantage. ${ }^{105}$

FDIC Board Member Jeremiah Norton similarly cautioned that SPOE could cause "the market equilibrium [to] shift in favor of [SIFI] subsidiaries" because "creditors of these subsidiaries could perceive that they would not take a loss upon distress at [a SIFI] and therefore would require a lower return on transactions or investments." 106 Thus, Mr. Hoenig and Mr. Norton recognized that SPOE could perpetuate the TBTF subsidy for SIFIs and their Wall Street creditors. ${ }^{107}$

\section{SPOE'S CLAIMED BENEFITS ARE HIGHLY DOUBTFUL AND DO NOT JUSTIFY BLANKET PROTECTION FOR WALL STREET CREDITORS OF FAILED SIFIS}

Advocates for SPOE assert that the strategy has two significant advantages. First, SPOE could avoid disruptions in financial markets by preserving a failed SIFI's operating subsidiaries as going concerns. ${ }^{108}$ Second, SPOE could reduce cross-border conflicts between home country and host country regulators when a global SIFI fails. ${ }^{109}$ SPOE would allow the home country supervisor to maintain control of the parent holding company's receivership, and the operating subsidiaries could be kept out of foreign insolvency proceedings. ${ }^{110}$ SPOE's assumed benefits have

\footnotetext{
105 Joe Adler, Likely Battle Ahead for FDIC's 'Single Point' Resolution Plan, AM. BANKER, Dec. 11, 2013, 2013 WLNR 30941803 (quoting comments by Mr. Hoenig).

106 Jeremiah D. Norton, Board Member, FDIC, Discussion on the Current State Resolution Planning, Remarks to the American Bankers Association (Oct. 21, 2013), available at https://www.fdic.gov/news/news/speeches/archives/2013/spoct2113.pdf.

107 Adler, supra note 105.

108 See supra notes 39-40, 46 and accompany text.

109 See supra note 41 and accompanying text.

110 See supra notes 40-41 and accompanying text.
} 
caused many U.S. and foreign regulators to express support for the strategy. ${ }^{111}$

It is very doubtful, however, whether SPOE's claimed advantages would actually be realized when a SIFI fails. As to the first alleged benefit, the commencement of an OLA receivership for a failed SIFI's parent holding company would likely have serious and potentially fatal spillover effects on its operating subsidiaries. Counterparties of subsidiaries might well decide to cut off credit lines and cancel other contracts instead of waiting to see whether the subsidiaries could survive as going concerns. ${ }^{112}$ For example, after Drexel Burnham Lambert's holding company declared bankruptcy in 1990, Drexel's two broker-dealer subsidiaries could not obtain even short-term credit from banks or other lenders, and the Securities and Exchange Commission was forced to place both broker-dealers in receivership. ${ }^{113}$ SPOE's ability to maintain a failed SIFI's subsidiaries as going concerns is therefore open to serious question, especially during a systemic financial crisis.

There is also great uncertainty about SPOE's ability to promote cross-border coordination when a global SIFI fails. Despite intensive efforts by the G20 and the FSB, developed countries have not agreed on an international framework for resolving global SIFIs. SPOE can work only with the cooperation of each host country in which a failed SIFI has a significant presence. For example, each host country must allow the home country supervisor to control the resolution of the SIFI's parent holding

\footnotetext{
111 See supra notes 38-46, 69-71 and accompanying text (quoting statements of support for SPOE by FDIC and BoE officials and noting the FSB's evident agreement with the concept); Guynn, supra note 35, at 284-86 (citing expressions of support for SPOE by U.S. and foreign regulators); 2014 Wall Street SPOE Letter, supra note 49, at 7-11 ("The FDIC's SPOE Strategy under Title II of Dodd-Frank has been widely praised [by U.S. and foreign regulators] and developed significant momentum ....").

112 Goodhart \& Avgouleas, supra note 68, at 10-12, 34 (describing the potential negative effects of "the dismemberment of the parent holding company").

113 Arthur E. Wilmarth, Jr., Wal-Mart and the Separation of Banking and Commerce, 39 ConN. L. REV. 1539, 1607 (2007); see also id. at 1606-09 (providing additional examples of contagion from troubled financial holding companies to their subsidiaries).
} 
company and must refrain from interfering with the SIFI's operating subsidiaries. ${ }^{114}$

At present, it is highly doubtful whether cross-border cooperation would be forthcoming if a global SIFI failed. Only a few nations have adopted SIFI resolution laws comparable to Title II of Dodd-Frank. ${ }^{115}$ The International Monetary Fund (IMF) recently concluded that "as yet, orderly resolution of systemic cross-border banks is not a feasible option."116 The IMF warned, "Should a large cross-border bank fail today, it appears unlikely that the pitfalls and misaligned incentives that undermined [international] cooperation in the global financial crisis could be avoided." 117

Similarly, the FSB recently reported that "most jurisdictions do not currently have statutory powers to recognise, enforce or give legal effect to foreign resolution measures."118 The FSB also cautioned that "very few jurisdictions currently have [cross-border resolution] frameworks in place,"119 and "no jurisdiction has experience" in applying such a framework to accomplish "the resolution of a complex, cross-border financial group." 120 In the absence of an effective international regime for resolving global SIFIs, host countries would likely use "ring-fencing" tactics to protect their citizens, including segregation and seizure of SIFIowned assets located in their jurisdictions. ${ }^{121}$

\footnotetext{
114 Goodhart \& Avgouleas, supra note 68, at 33-35, 40-44; Marc Jarsulic \& Simon Johnson, How a Big-Bank Failure Could Unfold, N.Y. Times Economix BloG (May 23, 2013, 12:01 AM), http://economix.blogs.nytimes.com/2013/05/23/how-a-big-bank-failure-could-unfold/.

115 U.S. GOV'T ACCOUNTABILITY OFFICE, GAO-14-261, INTERNATIONAL FINANCIAL REFORMS: U.S. AND OTHER JURISDICTIONS' EFFORTS TO DEVELOP AND IMPLEMENT REFORMS, 29-34 (2014), available at http://www.gao.gov/assets/670/662258.pdf.

116 InTERnational MONETARY Fund, CRoss-Border BANK RESOlution: Recent DEVELOPMENTS 4 (2014) [hereinafter IMF Bank Resolution Report] (bold type omitted), available at http://www.imf.org/external/np/pp/eng/2014/060214.pdf.

117 Id. at 23.

118 Fin. Stability BD., Cross-Border Recognition of Resolution Action: Consultative DOCUMENT 3 (2014), available at http://www.financeialstabilityboard.org/publications/c_1409 29.pdf.

119 Id. at 11.

$120 I d$. at 6.

${ }_{121}$ IMF Bank Resolution Report, supra note 116, at 5-7 ("Unilateral responses [by national authorities] were the norm" in dealing with troubled cross-border SIFIs during the recent
} 
Thus, SPOE's claimed advantages are doubtful at best and do not justify giving blanket protection to Wall Street creditors of failed SIFIs at the expense of ordinary investors and taxpayers. As discussed in Part III below, policymakers must adopt reforms to mitigate the impact of SPOE's shortcomings if SPOE is chosen as the preferred strategy for resolving failed SIFIs.

\section{POLICYMAKERS SHOUlD AdOPT Two REFoRMS To REDUCE THE TBTF SUBSIDY EMBODIED IN WALL STREET's SPOE PLAN}

U.S. and foreign regulators have expressed strong support for SPOE despite its flaws. ${ }^{122}$ In addition, regulators have not developed any alternative plan that could liquidate failed SIFIs during a systemic crisis without disrupting financial markets. ${ }^{123}$ Nor has Congress acted on legislative proposals that would force megabanks to become smaller and less complex, thereby removing (or reducing) the TBTF threat they pose to the financial sector and

\footnotetext{
financial crisis, "leading in some cases to the breakup of [SIFI] groups into national components"); $i d$. at 25-29 (noting that France, Belgium and the Netherlands could not agree on resolution plans for Dexia and Fortis and ultimately broke up both cross-border SIFIs into separate, nationalized banks); Paul Taylor, European Bank Mergers Still Face Hurdles PostStress Tests, REUTERS, Oct. 12, 2014, http://www.reuters.com/article/2014/10/12/us-ecb-banks-t ests-insight-idUSKCN0I105920141012 (describing "ring-fencing" strategies used by European bank regulators during the financial crisis and quoting former BoE Governor Mervyn King's observation that "global banks are global in life but national in death").

122 See supra notes 38-46, 69-71, 108-11 and accompanying text. In November 2015, after the manuscript for this article had been completed, the Federal Reserve Board (Fed) issued proposed rules that would require parent holding companies of U.S. G-SIBs and U.S. intermediate holding companies of foreign G-SIBs to maintain minimum levels of qualifying TLAC, including Tier 1 equity and long-term, bail-in debt. As I have described elsewhere, the Fed's proposed TLAC rules would (1) entrench SPOE as the chosen strategy for resolving failed G-SIBs and (2) finance such resolutions by wiping out investments made by shareholders and bail-in debtholders of the parent holding companies, with OLF loans as the ultimate backstop. The Fed's proposed TLAC rules would ensure that operating subsidiaries of failed G-SIBs and their creditors would receive full protection, while most or all of the resolution costs would be borne by ordinary investors and taxpayers. See Arthur E. Wilmarth, Jr., The Fed's TLAC Proposal Would Impose the Costs of Resolving Failed Megabanks on Ordinary Investors and Taxpayers, CLS BlUE SKY BLOG (forthcoming Dec. 2015).

${ }^{123}$ Lubben, supra note 64 , at 13-14; Skeel, supra note 64 , at 2-3, 9-10.
} 
the economy. ${ }^{124}$ It therefore appears likely that regulators will adopt SPOE as their preferred approach for resolving failed SIFIs.

If SPOE becomes the primary roadmap for OLA resolutions, policymakers must adopt two reforms that would force SIFIs and their insiders to internalize at least some of the costs of the systemic risks they create. First, SIFIs should pay risk-adjusted premiums to prefund the OLF. Those premiums should include fees on uninsured deposits and short-term shadow banking liabilities held by SIFIs. Second, SIFIs should pay at least half of their total compensation to senior executives and other key employees in the form of CoCos.

\section{A. SIFIS SHOULD PAY RISK-ADJUSTED PREMIUMS TO PREFUND OLF}

1. Prefunding OLF Would Reduce the TBTF Subsidy for SIFIs. I and other scholars have argued that Congress should require SIFIs to pay risk-adjusted premiums to prefund the OLF.125 This reform is urgently needed to correct a serious flaw in Dodd-Frank.

\footnotetext{
124 In 2010 the Senate rejected the Brown-Kaufman amendment, which would have imposed maximum size limits on banks and thereby mandated a breakup of the six largest U.S. banks. Wilmarth, Dodd-Frank, supra note 1, at 1055 n.454. Congress has also failed to adopt either (1) a Senate bill introduced in July 2013, which would reestablish the Glass-Steagall Act's mandatory separation between commercial banks and securities firms, or (2) another Senate bill introduced in April 2013, which would require SIFIs to hold much higher levels of equity capital and to stop using deposits from their FDIC-insured banks to subsidize the activities of their nonbank affiliates. See Peter Eavis, Senators Introduce Bill to Separate Trading Activities from Big Banks, N.Y. TIMES, July 11, 2013, http://dealbook.nytimes.com/2013/07/11/ senators-introduce-bill-to-separate-trading-activities-from-big-banks/ (discussing the "21st Century Glass-Steagall Act" introduced by Senators Maria Cantwell, Angus King, John McCain, and Elizabeth Warren); Wilmarth, Blind Eye, supra note 1, at 1440-44 (discussing the bill introduced by Senators Sherrod Brown and David Vitter in April 2013).

125 See, e.g., Viral V. Acharya et al., Taxing Systemic Risk, in REgulating Wall STREeT: The DodD-Frank ACT AND THE NEW ARChiteCtURE OF Global Finance 121, 137-40 (Viral V. Acharya et al. eds., 2011) [hereinafter REGULATING WALL StREeT] ("[S]ystemically important financial institutions need to internalize the systemic risk costs they imposed on the financial system."); Jeffrey N. Gordon \& Christopher Muller, Confronting Financial Crisis: Dodd-Frank's Dangers and the Case for a Systemic Emergency Insurance Fund, 28 YALE J. REG. 151, 154 (2011) (proposing a systemic risk insurance fund that would compel SIFIs to internalize the potential costs of their failure ); Wilmarth, Dodd-Frank, supra note 1, at 1015-23, 1049-50 (proposing that the FDIC should require SIFIs to pay risk-adjusted premiums to prefund the OLF); Wilmarth, Two-Tiered System, supra note 1, at 358-63 (presenting an updated proposal for prefunding the OLF).
} 
As discussed above, Dodd-Frank established the OLF to provide funding for the FDIC's liquidation of failed SIFIs, but Wall Street blocked legislative proposals that would have compelled SIFIs to pay premiums to prefund the OLF. ${ }^{126}$

Consequently, the OLF has a zero balance, and the FDIC will be obliged to impose retroactive assessments on large financial institutions to cover unpaid balances on OLF loans after resolving failed SIFIs. As previously shown, the FDIC would likely forebear from imposing assessments on surviving megabanks during a financial crisis. ${ }^{127}$ OLF borrowings would therefore remain unpaid until long after the crisis had passed. ${ }^{128}$

Thus, taxpayers will almost certainly be forced to underwrite resolutions of failed SIFIs via long-term OLF loans. The availability of OLF loans allows SIFIs to obtain short-term funding at artificially low, government-subsidized rates because short-term creditors of SIFIs expect to be fully protected during any future SPOE resolution. A prefunded OLF would shrink this subsidy for SIFIs and their creditors. ${ }^{129}$

I have proposed that banking firms with assets exceeding $\$ 100$ billion, together with nonbank financial companies designated as SIFIs under Dodd-Frank, should pay risk-adjusted premiums to prefund the OLF, over a period of several years, at a minimum level of $\$ 300$ billion. ${ }^{130}$ That level is justified by the fact that Treasury provided $\$ 290$ billion of capital assistance to the nineteen largest banks and AIG during the recent financial crisis. ${ }^{131}$ Each SIFI should pay risk-adjusted OLF premiums that reflect its contribution to systemic risk, based on factors such as size, complexity, opacity, leverage, liquidity, volatility of earnings, and interconnectedness with other large financial institutions. ${ }^{132}$

\footnotetext{
126 See supra notes 6-8, 92-101 and accompanying text.

127 See supra notes 93-101.

128 See supra notes 98-101 and accompanying text.

129 See supra notes 102-06 and accompanying text; Wilmarth, Two-Tiered System, supra note 1, at 358-60 ("A prefunded OLF is essential to shrink the TBTF subsidy for [SIFIs].").

${ }_{130}$ Wilmarth, Two-Tiered System, supra note 1, at 360.

$131 \mathrm{Id}$.

132 See Acharya et al., supra note 125, at 124, 138 (describing a multi-factor approach for determining each SIFI's contribution to aggregate systemic risk); Wilmarth, Dodd-Frank,
} 
Thus, OLF premiums should require each SIFI to "internalize" the systemic risk costs that it creates. ${ }^{133}$ The FDIC should use OLF premiums to cover losses from resolving a SIFI that remain unpaid after the FDIC has written off investments made by shareholders, holders of subordinated debt, and qualifying holders of bail-in bonds. If the FDIC uses OLF premiums to cover such losses, the FDIC should impose additional risk-adjusted premiums on large financial institutions to replenish the OLF. ${ }^{134}$

Requiring SIFIs to prefund the OLF would have several highly desirable outcomes. First, a prefunded OLF would help to protect Treasury and taxpayers from bearing the costs of resolving failed SIFIs. Second, a well-designed, risk-adjusted schedule for OLF premiums should encourage SIFIs to reduce their risks by following more prudent business strategies, maintaining stronger capital and liquidity positions, and adopting simpler, less complex business structures. Third, SIFIs would have strong incentives to monitor other megabanks and alert regulators when they observe aggressive risk-taking by their peers. Each SIFI would know that the failure of a peer institution would be likely to trigger additional OLF assessments. ${ }^{135}$ Fourth, a prefunded OLF would reduce the funding burden on prudent SIFIs by forcing high-risk megabanks to pay at least some OLF premiums before they fail. ${ }^{136}$

Fifth, a prefunded OLF would encourage regulators to resolve failed SIFIs promptly. A prefunded OLF would give the FDIC greater resources to resolve failed SIFIs without exposing taxpayers to the costs of OLF loans. In contrast, the presently unfunded OLF encourages regulators to delay putting troubled SIFIs into OLA receiverships in order to postpone (and hopefully avoid) the unpopular step of using taxpayer-backed OLF loans to finance the resolutions. ${ }^{137}$ For all of the above reasons, a

\footnotetext{
supra note 1, at 1021-22 (proposing that the OLF premiums paid by each SIFI should be based on various factors related to systemic risk).

133 Wilmarth, Dodd-Frank, supra note 1, at 1021-22. For a proposed methodology for measuring and taxing systemic risk, see Acharya et al., supra note 125, at 124-31, 138-40.

134 Wilmarth, Dodd-Frank, supra note 1, at 1019-20.

135 Id. at 1021

${ }^{136} I d$.

137 Wilmarth, Two-Tiered System, supra note 1, at 362.
} 
prefunded OLF would reduce the TBTF subsidy that otherwise would grow even larger under Wall Street's SPOE plan.

2. OLF Premiums Should Include Fees on Short-Term Liabilities Held by SIFIs. If regulators embrace SPOE with its guaranteed protection for short-term creditors of SIFIs, they must require SIFIs to pay for that protection. ${ }^{138}$ Accordingly, each SIFI's OLF premiums should include fees on its short-term liabilities. Those fees should be comparable to risk-based deposit insurance premiums and should be assessed on uninsured deposits and other short-term liabilities held by SIFIs and their operating subsidiaries.

SIFIs rely on cheap funding from government-subsidized, shortterm liabilities to finance their speculative activities in the capital markets. ${ }^{139}$ During the credit boom leading up to the financial crisis, megabanks expected that governments would protect all of their depositors (insured and uninsured) in order to preserve financial stability. Regulators fulfilled that expectation by providing bailouts that rescued failing megabanks and protected all of their depositors. ${ }^{140}$ SIFIs continue to rely on low-cost deposits to finance their capital markets activities. ${ }^{141}$

SIFIs also draw much of their short-term funding from shadow banking liabilities, including commercial paper, securities repurchase agreements (repos), and various types of asset-backed securities. ${ }^{142}$ Those instruments function as "shadow bank deposits" because they are "expected to be available on demand

\footnotetext{
138 See Levitin, supra note 65 ("If there's going to be a guarantee [for short-term liabilities of SIFIs under SPOE], it needs to be explicit and priced.").

139 See Wilmarth, Two-Tiered System, supra note 1, at 331-32 (explaining that WallStreet mounted a successful campaign to repeal the Lincoln Amendment to Dodd-Frank because SIFIs were determined to maintain their ability to conduct high-risk derivatives activities within their subsidiary banks so that they could "keep exploiting the cheap funding" provided by bank deposits).

140 Viral V. Acharya et al., A Bird's Eye View: The Dodd-Frank Wall Street Reform and Consumer Protection Act, in Regulating WALl Street, supra note 125, at 1, 2-5. See generally JOHNSON \& KWAK, supra note 86; Wilmarth, Two-Tiered System, supra note 1.

141 See Wilmarth, Two-Tiered System, supra note 1, at 350-52, 368-69 (describing the reliance of megabanks on low-cost deposits).

142 Pozsar et al., supra note 9, at 11-17, 22-32, 48-52.
} 
and [paid] at par."143 Shadow banking liabilities allow megabanks to obtain low-cost funding while avoiding deposit insurance premiums and, in some cases, higher capital requirements. ${ }^{144}$ Indeed, repos have provided a cheaper source of funding than bank deposits during the past several years. ${ }^{145}$

Investors in shadow banking liabilities include wealthy individuals, hedge funds, mutual funds, insurance companies, corporations, municipalities, and other institutional investors. ${ }^{146}$ Many of those investors have close connections to Wall Street megabanks. ${ }^{147}$ The financial crisis "demonstrated that shadow banking creates new channels of contagion and systemic risk transmission between traditional banks and the capital markets." 148 For example, about 90\% of the assets of "prime" money market mutual funds (MMMFs) consist of short-term liabilities issued by financial institutions, including "commercial paper, structured securities, bank obligations, and repurchase agreements." 149

During the financial crisis, markets for commercial paper and repos froze, and many MMMFs experienced runs by investors. ${ }^{150}$ To prevent a collapse of the financial system, federal agencies established a wide array of emergency programs to protect shadow

\footnotetext{
143 Id. at 52 .

${ }^{144} I d$. at $11-14,22-30$.

145 Eric S. Rosengren, President \& Chief Exec. Officer, Fed. Res. Bank of Boston, BrokerDealer Finance and Financial Stability, Keynote Remarks at the Conference on the Risks of Wholesale Funding, available at https://www.bostonfed.org/news/speeches/rosengren/2014/ 081314/081314text.pdf (referring to Figure 10 in the accompanying presentation, which is available at http://www.bostonfed.org/news/speeches/rosengren/2014/081314figuresandcom ments.pdf); see also id. at 8-10 (referring to Figures 6 and 8, which show that securities broker-dealers, including subsidiaries of universal banks, raise about half of their funding through repos).

146 BLINDER, supra note 1, at 59-60; Poszar et al., supra note 9, at 46-54; see also Viral V. Acharya \& T. Sabri Öncü, The Repurchase Agreement (Repo) Market, in REgulating Wall STREET, supra note 125, at 319, 322 (listing major participants in the repo market).

147 Tobias Adrian \& Adam B. Ashcraft, Shadow Banking Regulation, 4 ANN. REv. Fin. ECON. 99, 100 (2012) ("The operations of many shadow banking vehicles and activities are symbiotically intertwined with traditional banking and insurance institutions.").

${ }_{148} I d$.

149 Marcin Kacperczyk \& Philipp Schnabl, How Safe Are Money Market Funds?, 2013 Q. J. ECON. 1081 (noting that "prime" MMMFs hold assets other than government securities).

${ }^{150}$ Id. at 1083-90; Acharya \& ncü, supra note 146, at 332-40.
} 
banking creditors, including loans, guarantees, and asset purchases, which collectively provided a "360" backstop" for shadow banking liabilities. ${ }^{151}$ For example, Treasury guaranteed MMMF investors against further losses, the FDIC guaranteed new issuances of debt by financial holding companies, and the Federal Reserve System (Fed) purchased commercial paper and made loans to broker-dealers. ${ }^{152}$ Those federal programs pledged trillions of dollars to protect short-term creditors of large financial institutions, thereby serving as "modern-day equivalents of deposit insurance" for shadow banking liabilities. ${ }^{153}$

HSBC chairman Douglas Flint recently acknowledged that universal banks received an "implicit subsidy" during the financial crisis "[b]ecause investment banking operations were alongside society's deposits, [and] there was an implicit underwriting of all the debt within the operation because one would not risk the systemic panic that would happen if people thought their deposits were at risk ...."154 FDIC Vice Chair Thomas Hoenig has warned that universal banks continue to exploit the federal government's "safety net subsidy" by combining commercial banking with capital markets activities and by relying on "wholesale funding markets" that are "major sources of volatility in times of financial stress." 155 SPOE would perpetuate that subsidy by protecting short-term liabilities issued by SIFIs and their operating subsidiaries.

As part of their OLF premiums, SIFIs should pay fees on their uninsured deposits and other short-term liabilities. Those fees should be comparable to risk-based deposit insurance premiums and should reflect the credit, liquidity, and market risks inherent

\footnotetext{
151 Pozsar et al., supra note 9, at 59-64.

152 Id. at 61-64; BLINDER, supra note 1, at 144-49, 161-62; JOHNSON \& KWAK, supra note 86 , at $157-64$.

153 Pozsar et al., supra note 9, at 64; see also JOHNSON \& KWAK, supra note 86, at 157-74 (describing the emergency programs as "blank checks" for "bailing out Wall Street," and noting that "the special inspector general for [the Troubled Asset Relief Program (TARP)] estimated a total potential support package of $\$ 23.7$ trillion, or over 150 percent of U.S. GDP”).

1542014 Flint Testimony, supra note 83.

155 Thomas M. Hoenig, Vice Chair, FDIC, Can We End Financial Bailouts?, Address to the Boston Economic Club 7 (May 7, 2014), available at http://www.fdic.gov/news/news/speeches/ spmay0714a.pdf.
} 
in each SIFI's short-term liabilities. ${ }^{156}$ The FDIC should monitor changes in short-term funding strategies used by SIFIs, and the FDIC should impose fees on new types of short-term liabilities that serve as substitutes for deposits, commercial paper, or repos. ${ }^{157}$

Requiring SIFIs to pay fees on their short-term liabilities would help to shrink their TBTF subsidy. Those fees would (1) force SIFIs to internalize risks created by those liabilities, (2) encourage SIFIs to adopt more stable, longer-term funding strategies that reduce their reliance on volatile, short-term liabilities, and (3) help to prefund OLF, thereby improving the FDIC's ability to resolve failed SIFIs without relying on taxpayer-backed loans. ${ }^{158}$

\section{B. SIFIS SHOULD PAY AT LEAST HALF OF THEIR COMPENSATION TO SENIOR EXECUTIVES AND OTHER KEY INSIDERS IN THE FORM OF COCOS}

1. Universal Banks Provide Extraordinary Benefits to Insiders at the Expense of Taxpayers and Society. As shown above, universal banks rely on subsidized, low-cost funding from deposits and shadow banking liabilities to finance their capital markets activities, including underwriting, market making, and trading in securities and derivatives. ${ }^{159}$ Most of the largest global banks have adopted the universal banking model as their favored

\footnotetext{
156 See CARNELl, MACEY \& MilleR, supra note 22, at 500-01 (describing the FDIC's riskbased deposit insurance premiums).

157 See Tracy Alloway, Meet the New Shadow Bank (It's a Lot Like the Old Shadow Bank), BLOOMBERG, June 17, 2015, http://www.bloomberg.com/news/articles/2015-06-17/meet-thenew-shadow-bank-it-s-a-lot-like-the-old-shadow-bank- (reporting that financial institutions were creating "a host of new vehicles" in order "to fill the hole left by . . . a shrinking repo market").

158 See Acharya \& Öncü, supra note 146, at 343-44 (discussing proposals to require issuers of repos to pay fees similar to deposit insurance premiums); Adrian \& Ashcraft, supra note 147, at 130-32 (describing proposals to require issuers of MMMFs to pay assessments to create an "ex ante buffer" to protect their investors).

159 See supra Part III.A.2. Megabanks receive additional benefits from the preferential treatment given to repos and derivatives under the Bankruptcy Code and statutes governing insolvencies of banks and SIFIs. Large universal banks are the primary beneficiaries of that preferential treatment because they are leading issuers of repos and dominant dealers in derivatives. For discussions of this topic, which is beyond the scope of this Article, see generally CARNELL, MACEY \& MILLER, supra note 22, at 506-07; Wilmarth, Blind Eye, supra note 1, at 1361-62 and sources cited therein.
} 
business strategy. 160 The universal banking model creates a strong likelihood that serious problems occurring in one sector of the financial industry will spill over into other sectors and trigger a systemic crisis, as occurred during 2007-2009. To stop the spread of contagion, governments provided trillions of dollars of assistance to protect depositors and shadow banking creditors of universal banks. ${ }^{161}$

In addition to their huge systemic risks, universal banks have performed very poorly during the past decade, even after receiving massive benefits from their TBTF subsidy. ${ }^{162}$ As a prominent financial magazine recently stated, "It is hard to avoid the conclusion that global banks are...dysfunctional conglomerates."163 A prominent columnist for a leading financial

\footnotetext{
160 JOHNSON \& KWAK, supra note 86, at 208-09; see also Christine Harper, Breaking up Big Banks Hard to Do as Market Forces Fail, BloOMBERG, June 27, 2012, http://www.bl oomberg.com/news/articles/2012-06-27/breaking-up-big-banks-hard-to-do-as-market-forces-fail (explaining that large global banks have embraced the universal banking model); Kushal Balluck, Bank of Eng., Investment Banking: Linkages to the Real Economy and the Financial System, Q. BULL., 2015 Q1, at 1, 2, http://www.bankofengland.co.uk/publications/Documents/q uarterlybulletin/2015/ q1prerelease_2.pdf ("[M] ost [global banks] operate a universal banking model, providing other retail and corporate banking services-such as accepting deposits, making loans and facilitating payments-alongside their investment banking activities.").

161 JOHNSON \& KWAK, supra note 86, at 120-21, 174; Balluck supra note 160, at 2, 9-11; Matthew Richardson, Roy C. Smith \& Ingo Walter, Large Banks and the Volcker Rule, in REGULATING WALl STREET, supra note 125, at 181, 181-84, 190-96; Wilmarth, Dodd-Frank, supra note 1, at 963-67, 977-87; see also Arthur E. Wilmarth, Jr., The Transformation of the U.S. Financial Services Industry, 1975-2000: Competition, Consolidation, and Increased Risks, 2002 U. ILL. L. REV. 215, 451-76 (warning of the risks of universal banks several years before the financial crisis occurred).

162 E.g., Arthur E. Wilmarth, Jr., Citigroup: A Case Study in Managerial and Regulatory Failures, 47 IND. L. REV. 69, 70-72, 132-37 (2014) [hereinafter Wilmarth, Citigroup]; Wilmarth, Two-Tiered System, supra note 1, at 368-69, 369 n.518; Harper, supra note 160; Cocking up All Over the World, ECONOMIST, Mar. 7, 2015 [hereinafter Global Banks], http:// www.economist.com/node/21645731/; Oliver Ralph, Lex In-Depth: Universal Banks, FIN. TIMES, Mar. 29, 2015, http://www.ft.com/intl/cms/s/0/a21b7454-d243-11e4-ae91-00144feab7de. html\#slide0; see also Michael J. Moore, Yalman Onaran \& Nicholas Comfort, Biggest Global Banks Shrink Under Pressure from Regulators, BlOOMBERG, Feb. 27, 2015, http:// www.bloomberg.com/news/articles/2015-02-27/biggest-global-banks-go-to-pieces-under-pressu re-from-regulators (reporting that average returns on assets at ten of the largest global banks declined from $0.81 \%$ in 2006 to $0.22 \%$ in 2014 ).

${ }_{163}$ Global Banks, supra note 162; see also The Fall of the Universal Bank, ECONOMIST, Nov. 21, 2012, http://www.economist.com/node/21566439/print ("The promise of the crossselling financial supermarket has long been eclipsed by the destruction of shareholder value after the crash.”).
} 
newspaper similarly declared, "The universal banking model is broken ...."164

Despite the woeful performance of global megabanks, their top executives are determined to preserve the universal banking model. ${ }^{165}$ Their attitude is not surprising, since large financial conglomerates have provided immense benefits to senior executives and other key employees (including traders). Compensation in the financial industry rose rapidly between 1980 and 2006, as banks became larger and more complex, and in 2006 financial sector compensation reached its highest level (compared with pay in other industries) since the early 1930s. ${ }^{166}$ Top executives of megabanks prospered even as their shareholders received lackluster or negative returns. ${ }^{167}$ Meanwhile, taxpayers

164 Ralph, supra note 162.

165 Peter Coy, The Biggest Banks Aren't Ready to Shrink, BloOMBERG, Mar. 5, 2015, http:// www.bloomberg.com/news/articles/2015-03-05/bank-capital-rules-would-smaller-banks-reallybe-safer- (reporting that "most of the biggest global banks," including JPMorgan Chase and Goldman Sachs, "are fighting to stay big and important"); Ben McLannahan, BofA Says It Is Not 'Too Big to Manage," Fin. TIMEs, May 6, 2015, http://www.ft.com/intl/cms/s/0/12a73710-f 410-11e4-bd16-00144feab7de.html\#axzz3tUMKjvqi (quoting assertion by Bank of America Chair \& CEO Brian Moynihan, that the bank's "integrated model" produces "significant benefits" through "diversification of earnings streams, cost synergies and cheap funding"); Nathaniel Popper, JPMorgan Chase Insists It's Worth More as One Than in Pieces, N.Y. TIMES, Feb. 24, 2015, http://www.nytimes.com/2015/02/25/business/dealbook/jpmorgan-pushe s-back-against-suggestion-of-split.html?_r=0 (reporting on efforts by JPMorgan Chase Chair Jamie Dimon to preserve his bank's "basic model of providing the full range of financial services around the globe").

166 JoHnson \& KWAK, supra note 86, at 58-61; Thomas Philippon \& Ariell Reshef, Wages and Human Capital in the U.S. Financial Industry: 1909-2006, at 3-4, 16-22, 30 (Nat'l Bureau of Econ. Research, Working Paper No. 14644, 2009); Wilmarth, Blind Eye, supra note 1 , at 1406-07, 1420-21.

167 See Wilmarth, Citigroup, supra note 162, at 87-88, 114-17 (noting that Citigroup's senior executives received very high compensation, including almost $\$ 1$ billion paid to Sandy Weill, while Citigroup's shareholders suffered huge losses between 2003 and 2012); Harper, supra note 160 (describing the disparity between high compensation paid to top executives at Bank of America and Citigroup and the banks' underperforming stock prices, which were both trading below book value); Michael J. Moore, JPMorgan Worth One-Third More in Break-Up, Mayo Says, BLOOMBERG, Feb. 27, 2012, http://www.bloomberg.com/news/articles/2012-02-27/ jpmorgan-would-be-worth-more-if-split-up-mayo (quoting a research report by Michael Mayo, who observed that JPMorgan Chase's stock price declined by 2\% between 2004 and 2011, while the bank's top five executives received “over $\$ 600$ million of compensation”); Hugh Son \& Pamela Roux, Jamie Dimon Is Now a Billionaire, and He Got There in an Unusual Way, BLOOMBERG, June 3, 2015, http://www.bloomberg. com/news/articles/2015-06-03/jamie-dimonbecomes-billionaire-ushering-in-era-of-the-megabank-iagiwwl8 (reporting that Sandy Weill 
and society incurred tremendous costs when financial markets froze and governments were forced to bail out SIFIs and their creditors during the financial crisis. ${ }^{168}$

Perverse incentives in megabanks' compensation plans help to explain the stark disparity between insiders' extraordinary gains and outsiders' huge losses. SIFIs promised very large rewards to senior executives and other key insiders if they met short-term profit goals. ${ }^{169}$ Those rewards encouraged speculative bets that produced short-term earnings and bonuses for insiders but later inflicted gigantic losses on ordinary investors, the deposit insurance fund, taxpayers, and society. ${ }^{170}$ Compensation policies that encouraged excessive risk-taking were especially dangerous at megabanks, given their highly-leveraged capital structures and their reliance on explicit and implicit safety net subsidies. ${ }^{171}$ Many analysts and regulators agree that executive compensation policies at SIFIs must be reformed to remove incentives for shortterm gambling. ${ }^{172}$

and Jamie Dimon both became billionaires while building universal banks at Citigroup and JPMorgan Chase).

168 See Wilmarth, Blind Eye, supra note 1, at 1312-17 (listing some of the enormous costs of the financial crisis); Wilmarth, Two-Tiered System, supra note 1, at 257-67 (describing the federal government's massive assistance to the largest financial institutions during the crisis).

169 BLINDER, supra note 1, at 81-84, 283-85, 297; JOHNSON \& KWAK, supra note 86, at 5861, 115-16; Lucian A. Bebchuk \& Holger Spamann, Regulating Bankers' Pay, 98 GEO. L.J. 247, 249-74 (2010); John McCormack \& Judy Weiker, Rethinking "Strength of Incentives" for Executives of Financial Institutions, J. APPLIED CoRP. FIn., Summer 2010, at 65, 66-69; Frederick Tung, Pay for Banker Performance: Structuring Executive Compensation for Risk Regulation, 105 NW. U. L. REV. 1205, 1216-23 (2011); Wilmarth, Citigroup, supra note 162, at $99,104-05,114-19$.

170 See supra notes 166-69 and accompanying text (describing how bank compensation systems encouraged risk-taking, which eventually led to huge government bailouts).

171 Rosalind L. Bennett et al., Inside Debt, Bank Default Risk, and Performance During the Crisis 2-3 (FDIC Ctr. for Fin. Research, Working Paper No. 2012-3, 2014), available at http:// ssrn.com/abstract=2122619; McCormack \& Weiker, supra note 169, at 66; Tung, supra note 169, at 1210-16; Sjoerd van Bekkum, Inside Debt and Bank Risk, J. Fin. \& QUANTITATIVE ANALYSIS (forthcoming) (manuscript at 3-4), available at http://ssrn.com/abs tract=1682139; Wilmarth, Two-Tiered System, supra note 1, at 363 n.498.

172 See supra notes 169, 171, infra notes 173-77 and accompanying text (describing studies showing that equity-based compensation incentives encouraged disastrous shortterm risk-taking by insiders at large banks, while debt-based compensation plans motivated executives to adopt sustainable long-term business strategies that were less risky and better aligned with the interests of creditors). 
2. SIFIs Should Pay Much of Their Compensation to Insiders in the Form of CoCos. To change the incentives for insiders at megabanks, regulators should compel SIFIs to adopt compensation policies that include smaller equity-based incentives and a much larger focus on long-term debt. During the period leading up to the financial crisis, large banks assumed greater risks and suffered bigger losses if their executive compensation plans included strong equity-based incentives. ${ }^{173}$ Executives at those institutions made aggressive acquisitions, expanded nontraditional, fee-based businesses (including investment banking), and acquired large amounts of subprime mortgagebacked securities. ${ }^{174}$

In contrast, banks that issued larger amounts of long-term debt to their top executives performed significantly better during the financial crisis and had a substantially lower risk of default. ${ }^{175}$ Long-term debt compensation for executives (inside debt) includes pension rights and deferred compensation rights, which are "typically unfunded and unsecured" and therefore "face default risk just as outside creditors do."176 Executives holding a higher proportion of inside debt in relation to their equity interests had

\footnotetext{
173 Jens Hagendorff \& Francesco Vallascas, CEO Pay Incentives and Risk-Taking: Evidence from Bank Acquisitions, 17 J. CORP. FIN. 1078, 1078-79 (2011); see also authorities cited infra in note 174.

174 Robert DeYoung et al., Executive Compensation and Business Policy Choices at U.S. Commercial Banks, 48 J. Fin. \& QuANTITATIVE ANALYsis 165, 166-68, 175, 177, 180-83, 189, 192-95 (2013); Rüdiger Fahlenbrach \& René M. Stulz, Bank CEO Incentives and the Credit Crisis, 99 J. FIN. ECON. 11, 12-13, 24-25 (2011); Hagendorff \& Vallascas, supra note 173, at 1079-80, 1084-86, 1091-94; Bennett et al., supra note 171, at 1-6, 19-24, 36-37; see also Sanjai Bhagat \& Brian Bolton, Misaligned Bank Executive Incentive Compensation, 16, 13-14, 17-33 (June 11, 2013) (unpublished manuscript), available at http://ssrn.com/ abstract=2277917 (analyzing executive compensation plans at fourteen of the largest U.S. financial institutions between 2000 and 2008, and finding that (1) those fourteen institutions provided much larger amounts of equity-based pay to their chief executive officers, compared with thirty-seven smaller banks that did not receive TARP assistance; and (2) the same fourteen institutions incurred much greater risks and performed much worse during the financial crisis, compared with the group of thirty-seven smaller banks).

175 Bennett et al., supra note 171, at 3-6, 19-24, 34-37; Bekkum, supra note 171 (manuscript at 4-7, 17-26, 30-31); Frederick Tung \& Xue Wang, Bank CEOs, Inside Debt Compensation, and the Global Financial Crisis 3-5, 22-29 (B. U. Sch. of Law, Working Paper No. 11-49, 2012), available at http://ssrn.com/abstract=1570161.

176 Tung \& Wang, supra note 175, at 1, 6-7.
} 
incentives that were more aligned with long-term creditors and therefore adopted lower-risk business strategies prior to the financial crisis. ${ }^{177}$

The foregoing evidence supports the view that key insiders at SIFIs (including senior executives, traders and risk managers) should receive a large portion of their compensation in the form of long-term debt. I have previously argued that SIFIs should pay at least half of the total compensation for key insiders in the form of CoCos. ${ }^{178}$ CoCos for key insiders should be converted into common stock upon the occurrence of a designated event of financial stress, including (1) a decline in capital below a specified level or (2) the initiation of an OLA receivership, a bankruptcy, or another insolvency proceeding for a SIFI or one of its principal operating subsidiaries. The Fed, as the primary supervisor of the SIFI's parent holding company, should have the authority to activate any pre-insolvency trigger for financial distress.

Key insiders of SIFIs should be barred from making any voluntary conversions of their CoCos into common stock until three to five years after their employment ends. In addition, after voluntary conversions occur, insiders should be required to spread their sales of common stock over an additional period of similar length. Insiders should also be prohibited from using derivatives or other instruments to hedge their exposure to CoCos or common stock issuable upon conversion of CoCos.

A lengthy post-employment holding period for CoCos and a further deferral period for sales of common stock issued upon voluntary conversions of CoCos would discourage insiders from making high-risk gambles to boost the value of their equity-based compensation or the voluntary conversion option for their CoCos. Insiders would know that their CoCos would be automatically converted into common stock upon the occurrence of a designated triggering event indicating financial distress. Any common stock

\footnotetext{
177 See Bennett et al., supra note 171, at 36.

178 See supra notes 76-81 and accompanying text (discussing CoCos). The following description of my proposal to require SIFIs to pay much of their executive compensation in the form of CoCos is adapted from Wilmarth, Dodd-Frank, supra note 1, at 1008-09, and Wilmarth, Two-Tiered System, supra note 1, at 365-67.
} 
received upon mandatory conversion would likely have little or no value. Thus, CoCos would be a far more effective way of discouraging excessive risk-taking by insiders compared with complicated clawback provisions in employment contracts. ${ }^{179}$

Requiring key insiders to receive at least half of their total compensation in the form of CoCos, and to hold those CoCos (and any resulting common stock) for several years after their employment, would give them powerful incentives to adopt business strategies that are consistent with the interests of longterm creditors, the deposit insurance fund, the OLF, and taxpayers. CoCos would ensure that (1) insiders would not receive a significant portion of their compensation unless their organization achieves long-term success, and (2) insiders would bear a fair share of the losses if their institution encounters severe financial distress during their employment or within several years thereafter. ${ }^{180}$

Section 956(b) of Dodd-Frank requires federal regulators to issue rules barring incentive-based compensation plans that encourage "inappropriate" risk-taking by financial institutions. ${ }^{181}$ Regulators have not yet adopted final rules to implement Section 956(b), even though Dodd-Frank established a deadline of April 2011 for that action. ${ }^{182}$ Regulators should promptly issue final rules that would carry out the intent of Section 956(b) by incorporating the CoCo compensation plan for SIFIs described above. ${ }^{183}$

\footnotetext{
179 Wilmarth, Dodd-Frank, supra note 1, at 1008-09; Wilmarth Two-Tier System, supra note 1, at 365-67. For similar proposals to use CoCos to improve the incentives of key insiders of SIFIs, see Jeffrey N. Gordon, Executive Compensation and Corporate Governance in Financial Firms: The Case for Convertible Equity-Based Pay 8-14 (Ctr. for Law \& Econ. Studies, Columbia Univ. Sch. of Law, Working Paper No. 373, 2010), available at http:// ssrn.com/abstract=1633906; Wulf A. Kaal, Contingent Capital in Executive Compensation, 69 WASH. \& LEE L. REV. 1821, 1854-72 (2012).

180 Wilmarth, Dodd-Frank, supra note 1, at 1009.

181 Dodd-Frank, Pub. L. No. 111-203, § 956(b), 124 Stat. 1376, 1905 (2010).

182 Wilmarth, Two-Tiered System, supra note 1, at 367 \& n.517.

183 Id. at 367-68.
} 


\section{CONCLUSION}

The high-risk business model of universal banks was an important cause of the financial crisis. Universal banks rely on cheap funding from government-subsidized deposits and shadow banking liabilities to finance their speculative activities in the capital markets. By combining deposit-taking and lending with underwriting, market making, and trading in securities and derivatives, the universal banking model creates a strong likelihood that problems occurring in one sector of the financial industry will spread to other sectors. To prevent such contagion, federal regulators have powerful incentives to intervene during any serious disruption to protect universal banks and their depositors and short-term creditors. The support expressed by regulators for Wall Street's SPOE plan is a natural outgrowth of those incentives.

Wall Street's SPOE plan would guarantee future bailouts for Wall Street creditors while imposing losses from resolving failed SIFIs on ordinary investors and taxpayers. Wall Street's SPOE plan would also ensure that a failed SIFI would emerge from OLA with minimal structural changes. Thus, Wall Street's version of SPOE would preserve TBTF treatment for SIFIs and their Wall Street creditors. In a future crisis, ordinary citizens would be expected once again-whether as investors in bail-in bonds or as taxpayers - to rescue Wall Street from its reckless gambling.

Wall Street's SPOE plan is part of its broader campaign to defend the universal banking model. That business model has provided extraordinary benefits to insiders of SIFIs at the expense of ordinary investors, taxpayers, and society. A straightforward policy response would be to break up SIFIs by imposing maximum size limits or by requiring functional separation similar to the Glass-Steagall Act. ${ }^{184}$ However, Congress has declined to adopt either approach. ${ }^{185}$

\footnotetext{
184 See supra notes 5, 124 (describing proposals to impose maximum size limits on financial institutions and to enact a modern version of the Glass-Steagall Act).

185 See supra note 124 (discussing Congress' failure to adopt either reform). As an alternative remedy, I have proposed "narrow banking" reforms that would reduce
} 
Despite SPOE's serious flaws, U.S. and foreign regulators appear likely to adopt SPOE as their preferred strategy for resolving failed SIFIs. If SPOE does become the preferred approach, policymakers should adopt two reforms to reduce SPOE's subsidy for SIFIs and their insiders. First, SIFIs should pay risk-adjusted premiums (including fees on their uninsured deposits and short-term shadow banking liabilities) to prefund the OLF. Second, SIFIs should pay at least half of their total compensation for key insiders in the form of CoCos that are subject to lengthy post-employment holding periods.

The foregoing reforms would not eliminate the TBTF subsidy for megabanks. Those reforms, however, would compel SIFIs and their insiders to internalize at least some of the costs of the systemic risks they impose on society. Requiring SIFIs and their insiders to absorb those costs would encourage them to follow more sustainable, long-term business policies, and would also support current efforts by regulators to persuade SIFIs to reduce their size and complexity. ${ }^{186}$

government subsidies for SIFIs and increase market pressures for voluntary breakups by (1) establishing strict legal firewalls between banking and nonbanking subsidiaries of SIFIs, and (2) prohibiting SIFIs from using deposits from their "narrow banks" to finance their nonbanking activities. Wilmarth, Two-Tiered System, supra note 1, at 342-63.

186 See Moore, Onaran \& Comfort, supra note 162 (reporting that U.S. and foreign regulators have imposed tougher capital rules, stress tests, liquidity requirements, and resolution planning standards to encourage megabanks to become smaller and less complex). 
